\title{
ANTIMONOPOLISM AS A SYMPTOM OF AMERICAN POLITICAL DYSFUNCTION
}

\author{
Ramsi A. Woodcock ${ }^{*}$
}

\begin{abstract}
Contemporary American interest in using antitrust law to address wealth inequality is a symptom of American political dysfunction rather than a reflection of any intellectual advance regarding the sources of inequality. Indeed, both the original American progressives of a century ago, as well as Thomas Piketty, whose work sparked contemporary intellectual interest in inequality, agree that inequality's source is scarcity, rather than monopoly, and so will persist even in perfectly competitive markets. The only real solution is taxation, not a potentially destructive campaign of breakup. There are two causes of contemporary American antimonopolism. The first is American anti-statism, which has closed off tax policy as a viable political solution to inequality, forcing scholars and activists to seek a second- or third-best workaround in antitrust policy. The second is the American press, which is actively promoting antimonopolism as a way of fighting back against Google and Facebook, two companies that have badly outcompeted the press for advertising dollars in recent years. Given these idiosyncratic roots of contemporary American antimonopolism, other jurisdictions seeking to address inequality may have little to gain from following the American example, particularly if taxation remains a viable policy option for them.
\end{abstract}

\footnotetext{
* Assistant Professor, University of Kentucky Rosenberg College of Law, Secondary Appointment, Department of Management, University of Kentucky Gatton College of Business \& Economics. Participants at a 2021 Boston University Law Review Symposium on Law, Markets, and Distribution, a Yale Thurman Arnold Project workshop, and the conference titled "Should Wealth and Income Inequality Be a Competition Law Concern?", which was hosted online in 2021 by the Amsterdam Center for Law and Economics of the University of Amsterdam, provided helpful comments. This research was supported by a grant from the John S. and James L. Knight Foundation.
} 


\section{Table of Contents}

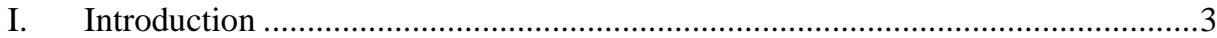

II. Scarcity, Not Monopoly, as the Major Cause of Inequality ...................................

A.Distinguishing Antimonopolism from Opposition to Inequality in Bargaining

Power More Generally

B. Two Scarcity-Based Critiques of Antimonopolism from the Left..........................8

1. The Original Progressive Critique of Antimonopolism ..................................8

a. The Original Progressives' Rejection of the Conservative Case for

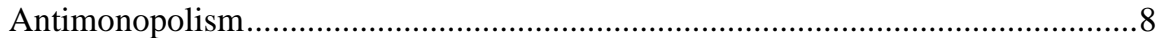

b. The Original Progressives' Understanding of the Meaning of Scarcity 17

c. Monopoly Power and Scarcity Power Distinguished ..........................20

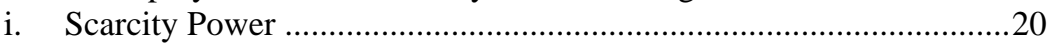

ii. Monopoly Power ...............................................................................23

d. The Generality of the Critique.............................................................28

e. The Original Progressive Recipe for Inequality .................................30

2. Piketty's Implicit Critique of Antimonopolism …………………….................33

III. Explaining Contemporary American Progressive Interest in Redistribution

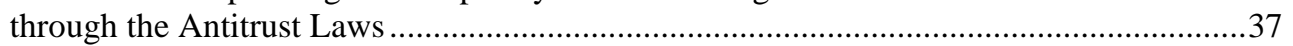

A.The Long March Around the Tax System in Legal Academia ................................37

B. The Press and Politicians .....................................................................................4

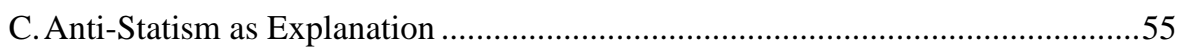

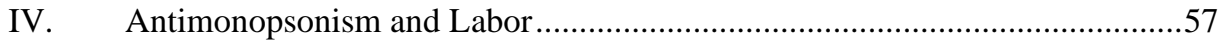

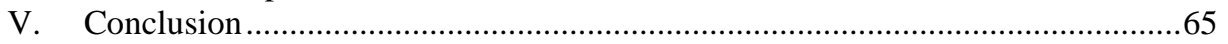




\section{INTRODUCTION}

Interest in some American policy circles in using antitrust to address the problem of wealth inequality largely results from political dysfunction unique to the United States - profound anti-statist resistance to reform of the tax system notwithstanding widespread popular discontent with wealth inequality - rather than from any new insight into the sources of inequality, and should therefore be treated with caution both by policymakers in the United States and in particular by policymakers in other countries not suffering from similar political dysfunction. Indeed, an enduring irony of the interest of contemporary American progressives in antitrust and inequality is that (1) the original progressive movement a century ago rejected antitrust as a viable means of addressing wealth inequality and (2) the major theoretical effort that returned inequality to the global policy agenda, Thomas Piketty's Capital in the Twenty-First Century, rejects it as well. ${ }^{1}$

Both the original progressives and Piketty recognized that the primary source of wealth inequality is not due to monopoly rents - profits derived from the creation of artificial scarcity-but rather to natural scarcity, whether attributable to resource constraints (i.e., Ricardian scarcity) or technological limitations (i.e., Schumpeterian scarcity). ${ }^{2}$ This means that inequality is not primarily a result of what antitrust practitioners call supracompetitive pricing: the sale of goods and services at prices above the prices that would obtain in a competitive market. Indeed even were a perfect regime of antitrust enforcement to drive all prices to competitive levels, inequality would remain a major and, indeed, growing problem, because, thanks to scarcity, the profits that firms would earn in the competitive market would continue to be very large. ${ }^{3}$

The only way to get at scarcity - as opposed to monopoly - rents is to redistribute wealth through the tax system, which effectively democratizes ownership of scarce resources, ensuring that everyone gets a cut. ${ }^{4}$ American progressives understood this a century ago, which is why it is difficult to

1 See ThOMAs PIKETTY, CAPITAL IN THE TwEnTy-FIRst CENTURY 537 (Arthur Goldhammer trans., 2017) ("Yet pure and perfect competition cannot alter the inequality $\mathrm{r}$ $>\mathrm{g}$, which is not the consequence of any market "imperfection." ). For the original progressives, and more on Piketty, see infra Section II.B.1.

${ }^{2}$ See David J. Teece \& Mary Coleman, The Meaning of Monopoly: Antitrust Analysis in High-Technology Industries, 43 ANTITRUST BULL. 801, 819-23 (1998); PIKETTY, supra note 1 , at 269-72.

${ }^{3}$ See Thomas PIKETTy, CAPITAL IN THE TwENTY-FIRST CENTURY 441 (2014).

${ }^{4}$ See infra Sections II.B.1.e, II.B.2. 
find much discussion of antitrust in the work of the major progressive theorists of the time, such as Robert L. Hale..$^{5}$ Instead, the original American progressives fought pitched battles to establish the income tax, the corporate tax, and rate regulation, which directly target scarcity rents. ${ }^{6}$

But since the 1980s, a resurgent and uniquely American anti-statism has made it politically impossible for American progressives to achieve redistribution of wealth through the tax system, and indeed has led to a major reduction in tax rates in the United States. ${ }^{7}$ The hostility to taxation has remained remarkably popular even in recent years, despite broad public concern about inequality. The result is that American progressives have sought to carry out their redistributive project through an attack on monopoly as a kind of second- or third-best alternative to taxation. They have been encouraged in this endeavor by the appeal of antimonopoly rhetoric to an American public that is culturally distrustful of large institutions, public or private. And they have been greatly aided by a news industry that has been disrupted by innovation in advertising and content distribution by the Tech Giants and sees a rejuvenated antitrust as a means of protecting its competitive position. ${ }^{8}$

But interest in antitrust among progressives and in the press has far outstripped the ability of scholars to justify its use as a tool for solving the inequality problem, and unreflective pursuit of this policy route threatens to waste progressive energies and lead governments down a dead end, one that would be potentially quite destructive if a great many large, highly productive, and high-paying firms are pulled apart along the way. ${ }^{9}$

\section{SCARCITY, Not MONOPOLY, AS THE MAJOR CAUSE OF INEQUALITY}

\section{A. Distinguishing Antimonopolism from Opposition to Inequality in}

\footnotetext{
5 For one of the few references to antitrust in Hale's work see ROBERT LEE HALE, Freedom Through Law: Public Control of Private Governing Power 401 (1952).

${ }^{6}$ See BARbara Fried, The Progressive Assault on LAISSEZ FAIRE: Robert Hale AND THE FIRST LAW AND ECONOMICS MOVEMENT 40, 68, 160-205 (1998); Reuven S. AviYonah, Corporations, Society, and the State: A Defense of the Corporate Tax, 90 VA. L. REV. 1193, 1212-31 (2004).

7 See IsaAc William Martin, The Permanent Tax Revolt: How the Property Tax TRANSFORMED AMERICAN POLITICS 2-15 (2008); W. Elliot BrownleE, Federal TAXATION IN AMERICA: A HISTORY 182-83 (3d ed. 2016).

8 See Ramsi A. Woodcock, Big Ink vs. Bigger Tech, TRUTH ON THE MARKET, https://truthonthemarket.com/2019/12/30/big-ink-vs-bigger-tech/ (last visited Apr. 7, 2020).

${ }^{9}$ See Robert D AtKinson \& Michael Lind, Big is BeAutiful: Debunking The Myth of SMall Business 64-67 (2019); Gerald F DaVis, Managed By the Markets: How FINANCE RESHAPED AMERICA 67-72 (2011).
} 


\section{Bargaining Power More Generally}

Antimonopolists' target is what they call "concentration of economic power," which they seem partly to dislike in itself-this is the "small is beautiful" strand of the movement-and partly to dislike because they believe such concentrations to lead either to inequality of wealth or to political power. ${ }^{10}$ Because antimonopolists believe that concentrations of economic power lead to political power through wealth-in their view, those with economic power are able to dictate political outcomes mostly by buying support, rather than, say, by leveraging whatever charisma is associated with economic power in its own right - it seems reasonable to view antimonopolists' complaints about inequality and political power as essentially a single complaint about wealth. ${ }^{11}$ It is this wealth-oriented strand of antimonopolism that will be considered here.

If by concentrations of economic power antimonopolists mean the possession of bargaining power in markets - the ability of one party to hold out for a better price because the other party needs a deal more than does the first - antimonopolists are certainly right to view concentrations of economic power as the root of wealth inequality. ${ }^{12}$ Virtually all wealth is valuable only to the extent that it can be exchanged. A rentier's parents might leave him a house and some cash, but the cash is useless unless he can exchange it either for consumption items or for paper rights to the proceeds of projects in which he wishes to invest it. And the value of the house to him-assuming he is able to live in it-will depreciate away to zero as leaks develop in the roof and termites gnaw at the foundations, unless he is able to exchange some of the cash for repairs as well. But

${ }^{10}$ See Phillip Longman, The Case for Small-Business Cooperation, November/December 2018 WASH. MONTHLY (Oct. 28, 2018), https://washingtonmonthly.com/magazine/november-december-2018/the-case-for-smallbusiness-collusion/.

11 See Lina Khan \& Zephyr Teachout, Market Structure and Political Law: A Taxonomy of Power, 9 DuKE J. CONST. L. PUB. POL'Y 57 (2014) (“[T] he wealth transfers in concentrated markets are political because they make big companies bigger and enrich their executives and shareholders, handing both the firm and top individuals more political power.").

${ }^{12}$ Recognition of the foundation of distribution in bargaining power dates at least to the original progressives. See Warren J. Samuels, The Economy as a System of Power and Its Legal Bases: The Legal Economics of Robert Lee Hale, 27 U. MIAMI L. REV. 261, 309-23 (1973); Herbert Hovenkamp, The First Great Law \& Economics Movement, 42 STAN. L. REV. 993, 1022 (1990) (noting that Richard T. Ely argued that "[u]nregulated bargaining enhances power that already exists and creates increasingly greater economic inequality."); Duncan Kennedy, The Stakes of Law, or Hale and Foucault Transformative Discourses in Postmodern Social Cultural and Legal Theory, 15 LEGAL STUD. FORUM 327, 328-30 (1991). 
bargaining power determines the value for which wealth can be exchanged. ${ }^{13}$ You might be the richest person in the world, but if you are desperate enough for a sip of water, and there is only one person who can provide it, you are, in fact, poor, because all your wealth will buy you no more than that sip. ${ }^{14}$ The monopoly seller of water will insist on that price. $^{15}$

But antimonopolists do not target all imbalances in bargaining power when they decry concentrations of economic power, as their emphasis on concentration, and their self-described antimonopolism, suggest. ${ }^{16}$ They mean instead to link the maldistribution of wealth to inequalities in bargaining power associated specifically with breakdowns in the competitive process. ${ }^{17}$ They hearken back to a midcentury golden age of antitrust enforcement in America in which enforcers broke up big companies, competition thrived, and wealth was more evenly distributed than it is today. ${ }^{18}$ Although they generally make the connection between competition and equality only implicitly, the implication is clear: they believe that the increase in inequality over the past half-century in the United States is due in significant part to a decline in competition. ${ }^{19}$ Or, conversely, they believe that restoring competition to American markets would go a long way toward solving the problem of inequality.

Critics on the right have long argued against a connection between monopoly and inequality on the ground that the relative wealth of buyers and sellers is indeterminate. ${ }^{20}$ In some markets, the buyers are rich and the sellers are poor, so monopoly progressively redistributes. ${ }^{21}$ In other

${ }^{13}$ See Duncan Kennedy, Law Distributes I: Ricardo Marx Cls, SSRN SCHOLARLY PAPER 29 (2021).

${ }^{14}$ See id.

15 See id.

${ }^{16}$ See Longman, supra note 10.

${ }^{17}$ See id.

18 See Sandeep Vaheesan, The Evolving Populisms of Antitrust, 93 NEB. L. REV. 370, 38395 (2014); Sandeep Vaheesan, Resurrecting a "Comprehensive Charter of Economic Liberty”: The Latent Power of the Federal Trade Commission, 19 U. PA. J. Bus. L. 645, 657-63 (2017); Longman, supra note 10.

19 See Longman, supra note 10. Curiously, the clearest statement of this position (albeit with a twist) comes not from a more centrist antitrust progressive, rather than an antimonopolist. See Einer Elhauge, Horizontal Shareholding, 129 HARV. L. REV. 1267, 1272 (2016) (arguing that horizontal shareholding in particular "helps explain why, as Professor Thomas Piketty has famously observed, income inequality has risen in . . recent decades"').

20 See Daniel A. Crane, Antitrust and Wealth Inequality, 101 CORNELL L. REV. 1171, 1184-1209 (2016).

${ }^{21}$ See id. 
markets, the reverse is true. ${ }^{22}$ On average, then, it is a wash: the effects of monopoly on inequality are likely not significant. ${ }^{23}$ Antimonopolists - who are mostly activists, not scholars - have so far dealt with this argument, as with all criticism, through denial and avoidance. ${ }^{24}$ But law scholars belonging to the broader progressive community in antitrust respond by pointing out that shareholders tend to be relatively wealthy as a class, and they are the residual claimants on most of what is sold in the economy, apart from the labor services sold by workers. ${ }^{25}$ Of course, workers are poorer than shareholders and breaking up any monopolies that workers in particular enjoy, thanks to unionization, would tend to increase inequality, not reduce it. ${ }^{26}$ But no one thinks workers have been using unions mostly to monopolize labor markets, rather than to counteract attempts by employers to monopsonize those markets, and even if workers were monopolizing labor markets, the antitrust exemption for unions would prevent antitrust enforcers from touching the gains that workers derive from their power. ${ }^{27}$ It follows that smashing monopoly and promoting competition through the antitrust laws should on average take money from rich shareholders and distribute it to everyone else, since competition drives down prices and hence profits for rich shareholders, and those lower prices constitute a transfer to the public at large, since everyone is a consumer. ${ }^{28}$ That will tend to reduce inequality. ${ }^{29}$ This is probably a good rejoinder to the right's critique, insofar as it establishes that a return to competition from a baseline of monopoly is likely to be progressive in its effects on the distribution of wealth. ${ }^{30}$ The deeper question is, however: how progressive?

It is here that the critique of antimonopolism from the left, rather than the right, begins.

\footnotetext{
${ }^{22}$ See id.

${ }^{23}$ See id.

${ }^{24}$ See Woodcock, Big Ink vs. Bigger Tech, supra note 8.

${ }^{25}$ See Jonathan B. Baker \& Steven C. Salop, Antitrust, Competition Policy, and Inequality, 104 GeO. L.J. ONLINE 1, 11-12 (2015) ("The returns from market power go disproportionately to the wealthy--increases in producer surplus from the exercise of market power accrue primarily to shareholders and the top executives, who are wealthier on average than the median consumer."); $c f$. Crane, supra note 20, at 1207-9.

${ }^{26}$ Cf. FRIED, supra note 6, at 203-4; Crane, supra note 20, at 1208.

${ }^{27}$ See Herbert Hovenkamp, Is Antitrust's Consumer Welfare Principle Imperiled?, 45 J. CORP. L. 101, 13 (2019); Suresh Naidu et al., Antitrust Remedies for Labor Market Power, 132 HARV. L. REV. 536, 570 (2018).

28 See Rory Van Loo, Broadening Consumer Law: Competition, Protection, and Distribution, 95 Notre DAME L. REV. 211, 231-42 (2020).

${ }^{29}$ See id.

${ }^{30}$ See id.
} 


\section{B. Two Scarcity-Based Critiques of Antimonopolism from the Left}

The trouble with antimonopolism is that its end goal of competition is unlikely greatly to reduce inequality or even to stop the West's current slide toward greater inequality. ${ }^{31}$ There is a simple explanation for this, one that was advanced by progressive lawyers and economists in the first law and economics movement a century ago. ${ }^{32}$ There is also a contemporary explanation, due to Thomas Piketty, the foremost student today of the growing wealth gap in the West, one that builds on the original progressive account.

\section{The Original Progressive Critique of Antimonopolism}

a. The Original Progressives' Rejection of the Conservative Case for Antimonopolism

It is not without irony that the original progressive movement of a century ago - that of John R. Commons, Richard T. Ely, Robert L. Hale, and many others-developed its critique of antimonopolism partly in response to an attempt by a conservative economist-J. B. Clark- to advocate precisely what progressive antimonopolists call for today: a world of perfect competition justified on moral grounds. ${ }^{33}$ But unlike today's antimonopolists, who tend to assume without argument that the competitive price is the just price - or at least the lowest possible price that an undeserving monopolists can be made to charge - Clark tried to construct a detailed theory to explain why he thought competitive pricing was morally right. ${ }^{34}$ The competitive price is just, he claimed, because the competitive price pays sellers an amount equal to their marginal contribution to the

\footnotetext{
${ }^{31}$ See PIKETTY, supra note 1 , at 441.

${ }^{32}$ For overviews of the first law and economics movement, see FRIED, supra note 6, at 129; Hovenkamp, supra note 12, at 993-95.

33 See John BAtes Clark, The Distribution of Wealth: A Theory of Wages, INTEREST AND PROFITS 345 (1899) ("The entrepreneur who hires land does not make over the rent to the landlord because, after paying other claims, he has a certain remainder in his possession. That fact would never compel him to part with the remainder. He pays over this remainder, indeed; but he does it because each bit of land has a positive power to produce, and the landlord can make the tenant pay the value of the specific product of it. If this particular entrepreneur will not pay for a piece of land what it produces, another will. Competition forces the user of any productive agent to give to the owner of it the amount that it brings into existence."); FRIED, supra note 6, at 131-34; Hovenkamp, supra note 12, at $1022 \&$ n. 159.

${ }^{34}$ See Longman, supra note 10; CLARK, supra note 33, at 345.
} 
value they create for buyers. ${ }^{35}$

It is certainly true that the competitive price pays sellers an amount equal to their marginal contribution to the value they create for buyers. When markets are perfectly competitive, buyers enter the market until there are no buyers left who are willing to pay the market price but who have not had the chance to buy. Assuming the market is deep enough that there are some buyers willing to buy at every possible price, it follows that some buyers who place a value on the good that is just equal to the good's market price will buy the good. These are known as the marginal buyers in the market and the units they buy are the marginal units sold by sellers. ${ }^{36}$ Assuming that all sellers charge the same, uniform price (of which more in a moment), the price paid to sellers on every unit they sell, including both the units sold to the marginal buyers and the units sold to all other buyers, must equal the marginal benefit contributed by the sellers to the market (Figure 1). ${ }^{37}$

\footnotetext{
${ }^{35}$ See ClARK, supra note 33, at 345.

36 See Hal R. VArian, Intermediate Microeconomics: A Modern APProach (7th ed. 2006).

37 There is no cost curve drawn in Figure 1 because Clark's argument centered on the benefits conferred by production - the marginal product-not the costs of production. See FRIED, supra note 6, at 133 ("The 'marginal product,' Hale argued, formally measured the value to the purchaser of a given input, not the cost to the supplier of providing it. In fact, Clark's marginal productivity theory contained no theory of costs at all.").
} 


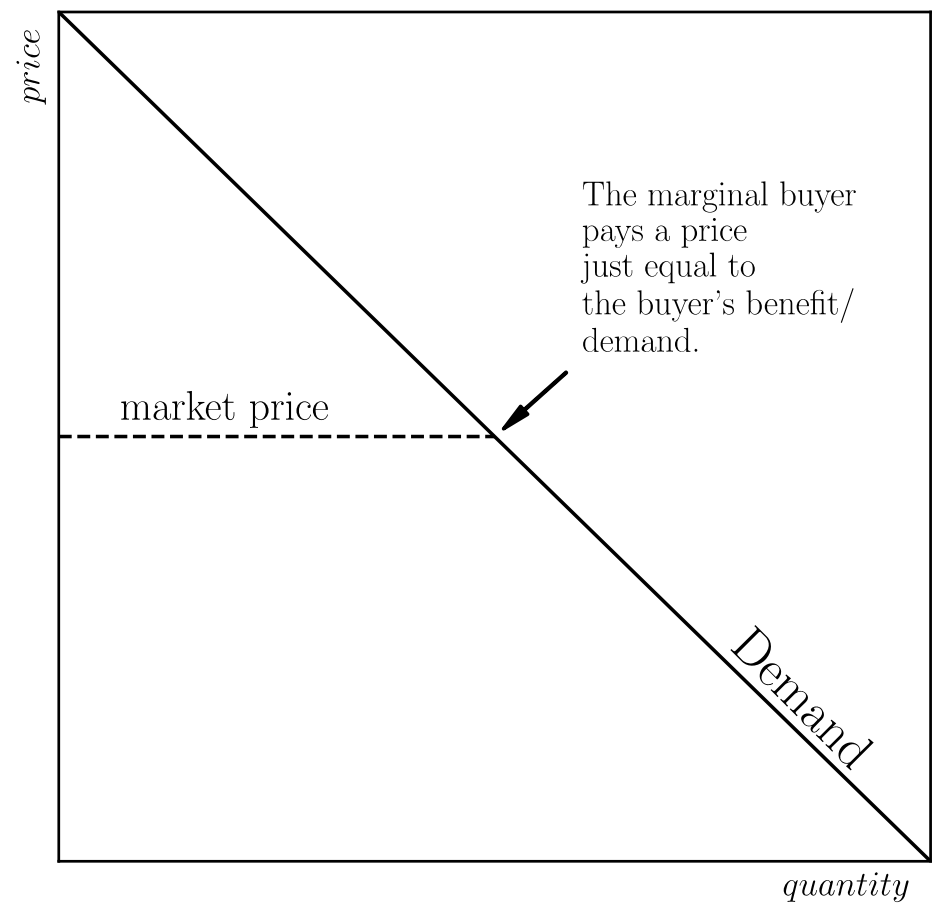

Figure 1

It is as difficult today to understand why Clark placed moral significance on the fact of sellers being paid their marginal contribution to buyer value as it seems to have been for progressives to understand this argument a century ago. ${ }^{38}$ Clark's explanations read so much like

\footnotetext{
${ }^{38}$ See Hovenkamp, supra note 12, at 1022 \& n. 159; FRIED, supra note 6, at 132 (observing that "Clark's particular brand of naive apologetics was a source of embarrassment for most mainstream economists"). We can perhaps rescue Clark as follows: his argument is that the marginal benefit conferred by the seller, which in a competitive market equals the seller's own marginal cost of producing the marginal units, provides a reasonable baseline regarding what the market expects the costs of production of all units to be. $C f$. CLARK, supra note 33, at 345. Certainly, it represents the maximum price that buyers in the market as a group (including the marginal buyers) are willing to pay for production: at a higher price, the market would buy at least one less unit since the marginal buyer would be priced out. It follows that any producer who is able to produce at a cost below the cost of producing the marginal units has excelled, in some sense, relative to the baseline, and so is entitled to keep the difference. It is the moral equivalent of price-cap regulation in public utilities law. See W. KIP VISCUSI ET AL., ECONOMICS OF REGULATION AND ANTITRUST (5th ed. 2018). Marginal cost pricing is the cap understood as the cost the seller is expected to have. Any profits the seller realizes by generating efficiencies that allow the seller to sell at a cost below the price cap are the seller's to keep because the seller is understood to have earned them by beating expectations.
} 
restatements of the mathematics of marginalist economics, rather than moral arguments, that one is tempted to see him as the earliest victim of the tendency of economists to fetishize mathematical models. ${ }^{39}$ Progressives responded, in any case, by pointing out that the marginal product of a good is completely untethered from the distribution of wealth between buyers and sellers created by competitive pricing. ${ }^{40}$ The wealth created in any market is the excess of the maximum buyers are willing to pay for the product - a measure of the benefits the product confers on them-and the cost to sellers of producing the product - cost being a measure of the value that sellers place on the product. ${ }^{41}$ The benefits conferred on buyers are represented by the consumer demand curve, and the costs to sellers are represented by the producer supply curve. ${ }^{42}$ The excess of benefit over cost is, then, equivalent to the excess of demand over supply and is called the surplus (Figure 2). ${ }^{43}$

39 See ClARK, supra note 33, at 193; Deirdre McCloskey, The Trouble with Mathematics and Statistics in Economics, 13 HISTORY OF ECONOMIC IDEAS 85, 90 (2005); Paul M. Romer, Mathiness in the Theory of Economic Growth, 105 AM. ECON. REV. 89, 93 (2015).

${ }^{40}$ See FRIED, supra note 6, at 133-34.

${ }^{41}$ See VARIAN, supra note 36.

42 See id.

${ }^{43}$ See Michael D. Guttentag, Law and Surplus: Opportunities Missed, 2019 UTAH L. REV. 607, 609 (2019); Ramsi A. Woodcock, The Antitrust Case for Consumer Primacy in Corporate Governance, 10 UC IRVINE L. REV. 1395, 1403 (2020); Ramsi A. Woodcock, Big Data, Price Discrimination, and Antitrust, 68 HASTINGS L.J. 1371, 1380-81 (2017). 


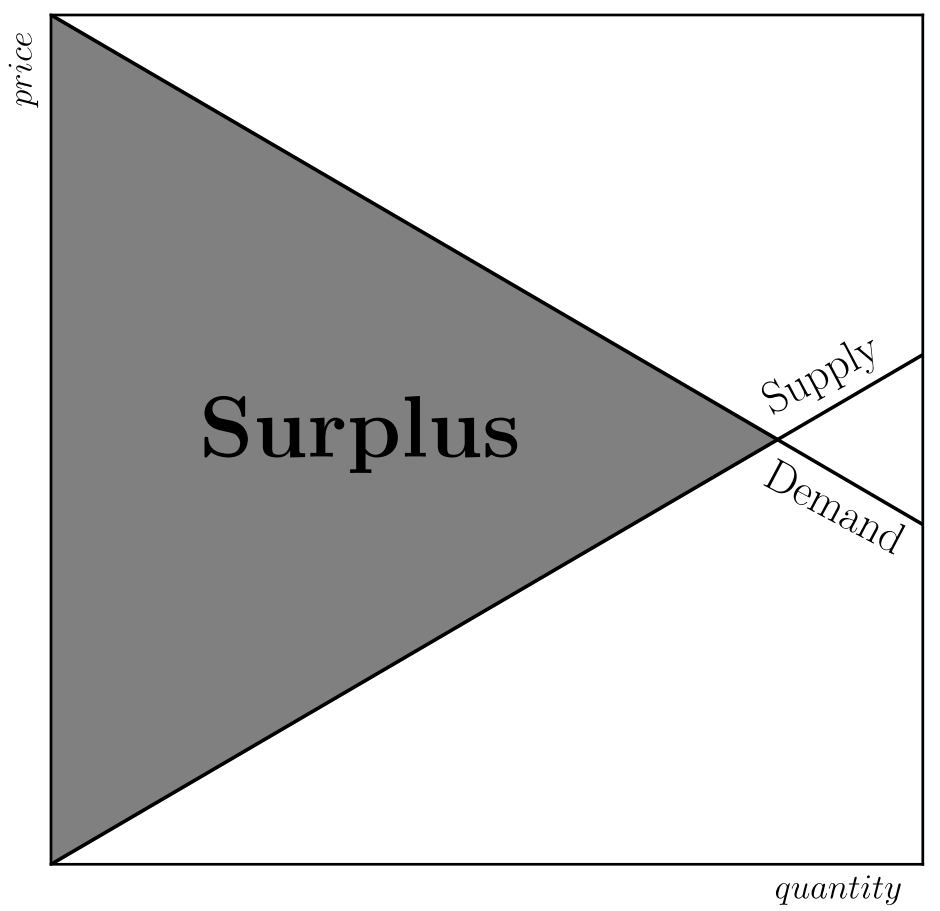

Figure 2

Price divides the surplus between buyers and sellers because price is that which buyers give up to sellers to enjoy the benefits represented by the demand curve and therefore subtracts from the surplus that buyers enjoy. ${ }^{44}$ And price is also that which sellers receive to compensate for the loss of the value to sellers represented by the supply curve, and the excess of price over that value is therefore sellers' share of the surplus they generate. ${ }^{45}$ In a perfectly competitive market, price is driven to the point at which all willing buyers find sellers and vice versa - that is, to the point at which the market clears. ${ }^{46}$ That market-clearing price is entirely determined by the maximum willingness to pay of the marginal buyer - the buyer with the lowest willingness to pay of all those who actual do buy - and the cost of the marginal seller - the seller with the highest cost of all sellers who actually do sell (Figure 3$)^{47}$

\footnotetext{
${ }^{44}$ See VARIAN, supra note 36; Woodcock, Big Data, Price Discrimination, and Antitrust, supra note 43 , at $1380-81$.

${ }^{45}$ See VARIAN, supra note 36.

${ }^{46}$ See id.

${ }^{47}$ See id.
} 


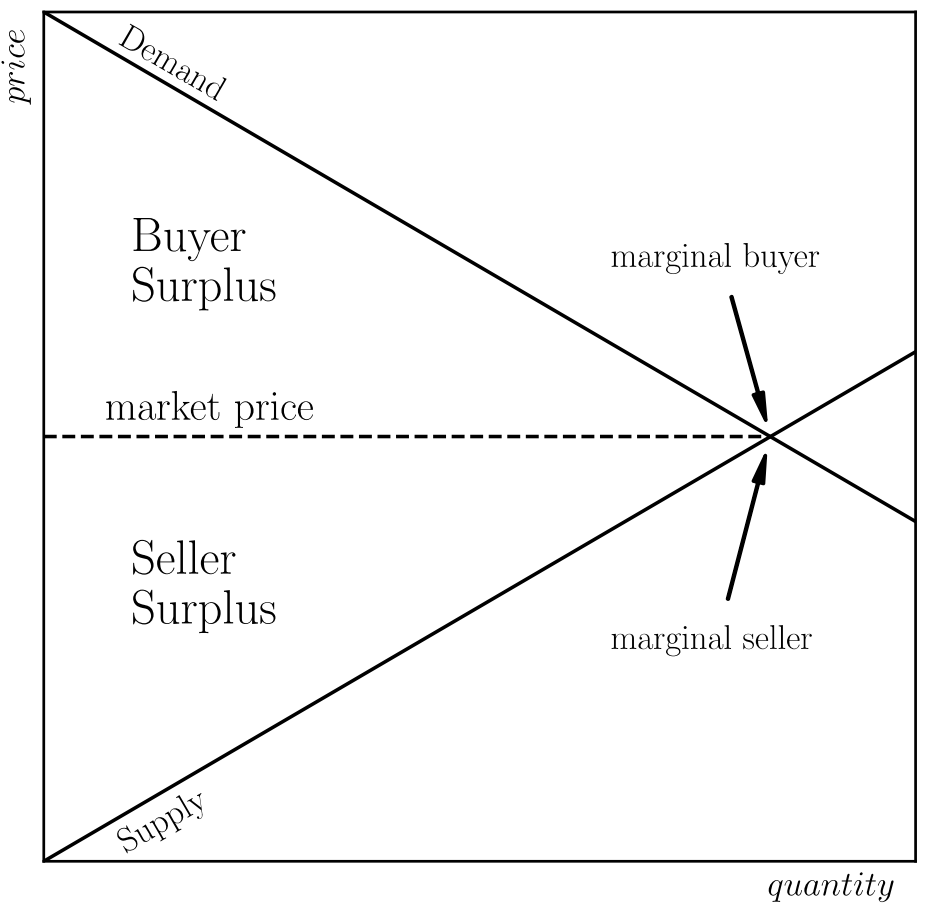

Figure 3

But the division of the surplus created by the competitive price is not determined by the marginal buyer and seller alone, but rather by the relationship between the marginal buyer's maximum willingness to pay and the maximum willingness to pay of all the other buyers, and the relationship between the marginal seller's costs and the costs of all the other sellers. ${ }^{48}$ That is, the distribution of wealth in a competitive market is determined as much by the inframarginal buyers and sellers as by the marginal buyers and sellers. ${ }^{49}$ Consider this point from a slightly different angle. In a market in which there are some buyers willing to buy at every price and there are some sellers willing to sell at every price (though not always in the same amounts), the price that the marginal buyer pays for the good equals the cost of production of that good, because if not then some more costly goods could be brought to market and buyers willing to buy them could be found.

48 See FRIED, supra note 6, at 134 ("Although marginal analysis gave an analytical structure for generalizing Ricardian rent theory to all factors of production, it said nothing about the actual incidence of rents - that is, the extent of producer's surplus accruing to a given factor. For that, one needed two things: a normative theory of what ought to count as a cost, and an empirical guess about the shape of the cost curve.").

${ }^{49}$ See id. 
But if the price that the marginal buyer pays for the good equals the cost of production of that good, then the surplus created by the transaction between the marginal buyer and seller is zero. So where is the surplus created by markets? (Markets must create surplus in order for economic activity to make society better off, and in general we do think that economic activity has made society better off. ${ }^{50}$ ) The answer is that the surplus is generated through all the transactions in the market between inframarginal buyers (who necessarily are willing to pay more than the competitive price because the marginal buyer by definition is willing to pay the least) and sellers of inframarginal units (who necessarily have costs below the competitive price because the marginal units must have the highest costs). ${ }^{51}$ Because the values inframarginal buyers place on the good exceed the market price and the costs incurred by sellers on inframarginal units are below the market price, there is an excess of benefit over cost for each transaction in which these buyers and sellers engage, meaning that surplus is created. ${ }^{52}$

How price divides that surplus is determined by how much more value the inframarginal buyers place on the good relative to the marginal buyer and how much lower sellers' costs on inframarginal units are relative to sellers' costs on marginal units. ${ }^{53}$ If inframarginal buyers place a very high value on the good relative to the value placed on it by the marginal buyer, but the sellers' costs on inframarginal units are not much below their costs on the marginal unit, then the competitive price will be close to sellers' costs for all units-yielding the sellers little surplus-but much below buyers' willingness to pay for all but the marginal unit, yielding buyers the lion's share of the surplus (Figure 4). ${ }^{54}$

50 See Brad DeLong, Estimates of World GDP, One Million B.C.-Present, https://delong.typepad.com/print/20061012_LRWGDP.pdf.

${ }^{51}$ See FRIED, supra note 6, at 26.

${ }^{52}$ See Woodcock, Big Data, Price Discrimination, and Antitrust, supra note 43, at 138081.

${ }^{53}$ See FRIED, supra note 6, at 134.

${ }^{54}$ See id. at 126-27 ("As Wicksteed, Wicksell, and J. B. Clark saw, Ricardian land rents were just a special case of the general principle that rents will accrue to the more productive [that is, inframarginal] units of any factor that is not reproducible at constant costs. Thus, Ricardo's assumption of an absolutely fixed supply of land was just 'a limiting case of the infinite array of possible supply elasticities.' As Hale maintained, whenever supply cannot be readily altered at costs that do not increase with quantity, the 'owners of superior resources,' in the form of scarce land or capital equipment acquired for lower than reproduction cost, will realize a surplus return in excess of costs. While early marginalist analysis concentrated on rents accruing to land and other forms of concrete capital, the same logic suggested that rents should accrue to labor and pure capital as well. In Marshall's terms, there will be a 'worker's surplus' or 'saver's surplus' whenever one is remunerated for work or waiting, respectively, at a price [determined by the marginal 


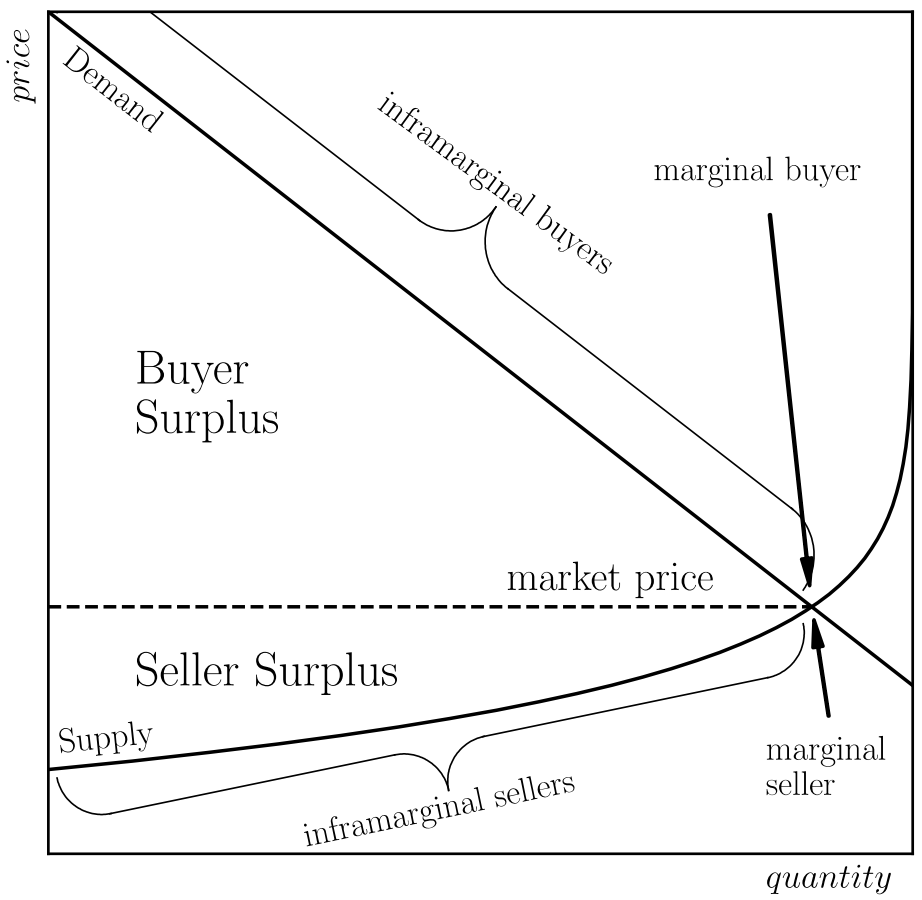

Figure 4

By contrast, if inframarginal buyers place a low value on the good relative to the value placed on it by the marginal buyer, but the sellers' costs on inframarginal units are much below their costs on the marginal unit, then the competitive price will be much above sellers' costs for all most units - yielding sellers the lions' share of the surplus - but not much below buyers' willingness to pay for all but the marginal unit, yielding buyers very little surplus (Figure 5). ${ }^{55}$

productivity of one's labor or capital] that exceeds the minimum amount that one would have demanded to provide it - in short, whenever one is an inframarginal supplier.").

${ }^{55}$ See id. 


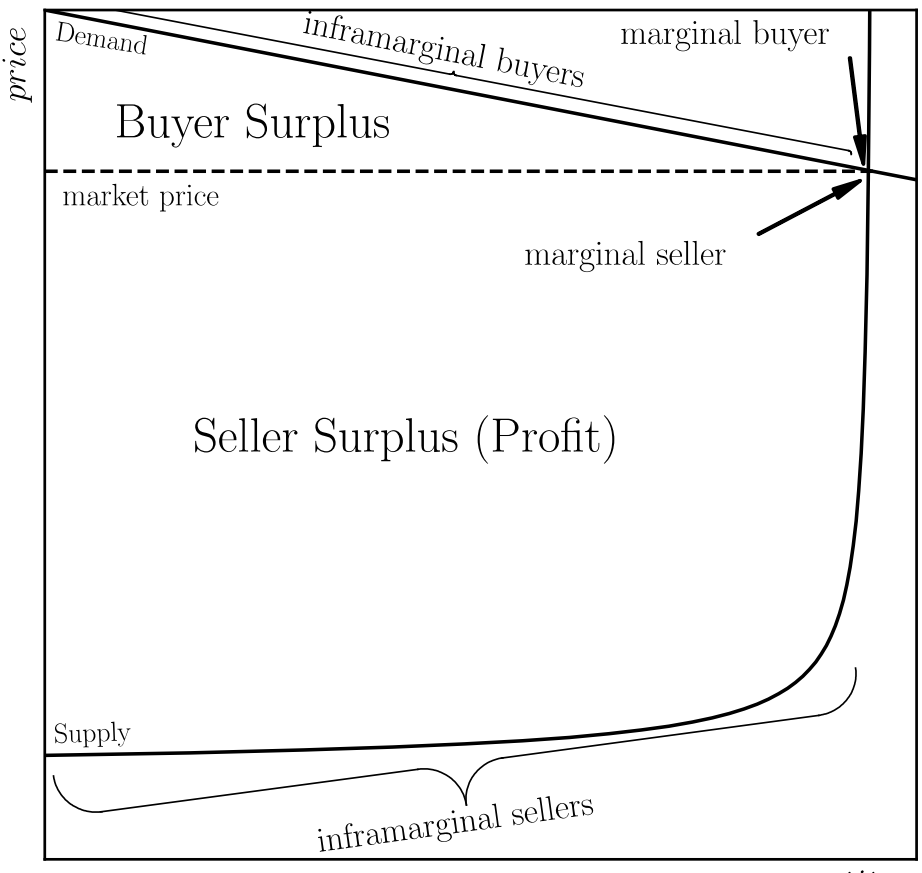

quantity

Figure 5

Whether the competitive price is fair in the sense that it divides the surplus equally between buyers and sellers, or fair in the sense that it minimizes the surplus enjoyed by sellers, or fair in any other distributive sense, depends on the values placed on the good by inframarginal buyers and sellers relative to the values placed on the good by the marginal buyer and seller; the fact that at the competitive price sellers are paid the marginal benefit they confer on consumers is just the starting point of the analysis and of no moral significance, at least insofar as distributive justice is concerned. ${ }^{56}$ All that competitive pricing guarantees is efficiency in the sense that it clears markets. ${ }^{57}$ At the competitive price, all willing buyers will find willing sellers and vice versa, and so surplus will be maximized. ${ }^{58}$ But how that surplus will be divided between buyers and sellers will be an arbitrary function of the relative magnitudes of the value placed on the good by the marginal buyer and seller and the values placed on the good by the

\footnotetext{
56 See id. at 134.

${ }^{57}$ See VARIAN, supra note 36.

${ }^{58}$ See id.; Woodcock, The Antitrust Case for Consumer Primacy in Corporate Governance, supra note 43, at 1409.
} 
inframarginal buyers and sellers. ${ }^{59}$

This critique certainly dispatched Clark's claim to the abstract moral superiority of competitive pricing. ${ }^{60}$ And it seemed to imply that antimonopolism, which at the time was a major political force in the United States, was wrongheaded: promoting competition would not necessarily lead to a desirable distribution of wealth. ${ }^{61}$ But this did not fully eliminate the appeal of antimonopolism. For just because competitive pricing can result in undesirable distributions of wealth does not mean that it must result in undesirable distributions. If costs tend to be uniform over all sellers, or nearly so (Figure 4), then competitive pricing will tend to allocate all of the surplus to buyers. ${ }^{62}$ And if sellers tend to be richer than buyers, the result will be progressive redistribution that is potentially radical in magnitude if sellers are never able to extract much surplus from their transactions. ${ }^{63}$ It is somewhat surprising how few progressive intellectuals of this era seem to have accepted this view, however. ${ }^{64}$

Instead, progressives appear to have found it self-evident that this argument failed to take into account the problem of scarcity.

\section{b. The Original Progressives' Understanding of the Meaning of Scarcity}

Some inputs into the production process are scarce. ${ }^{65}$ They may be raw materials, management talent, information, experience, or what have you. ${ }^{66}$

${ }^{59}$ See FRIED, supra note 6, at 134.

${ }^{60}$ See id. at 132-34.

${ }^{61}$ See Richard HofSTAdTER, THE AGE OF REFORM 227-56 (1960).

${ }^{62}$ See FRIED, supra note 6, at 134 ("Marginalism disproved the classical assumption that in competitive markets, prices would coincide with costs. More precisely, it showed that assumption held true only where inputs were reproducible at constant costs - in other words, where supply was completely elastic. In all other cases, the owners of scarce resources would receive 'economic rents' in excess of costs.").

${ }^{63}$ See Baker \& Salop, supra note 25, at 11-12.

${ }^{64} \mathrm{Cf}$. FRIED, supra note 6, at 26 ("Hale and the other progressive rent theorists were sympathetic to the antimonopoly wing of progressivism. . . But, beginning with the Fabian socialists in 1870s, they launched a third, distinct attack on the distributive justice of the market. Like the antimonopolists, they largely took as given the Marshallian bipolar model of the economy; however, they focused instead on the pole of so-called perfect competition."); William E. Kovacic, Failed Expectations: The Troubled Past and Uncertain Future of the Sherman Act as a Tool for Deconcentration, 74 IOWA L. REV. 1105, 1128-29 (1989) ("Most professional economists and academicians expert in corporate law initially treated the passage of the Sherman Act and its early enforcement with indifference or outright disapproval.").

65 See Harold Demsetz, Industry Structure, Market Rivalry, and Public Policy, 16 J.L. \& ECON. 1, 2-3 (1973).

${ }^{66}$ See id. 
Whatever input it may be that scarcity strikes, the result is the same: the sellers who have access to the input face lower production costs than the sellers who do not. ${ }^{67}$ Those unfortunate sellers who do not must either pay a premium to acquire the resource or use an inferior substitute. The inferior substitute either costs more to acquire or results in a poorer quality product, which latter must be sold at a lower profit to remain competitive, and is therefore equivalent, from the seller's perspective, to a product that is less profitable due to higher costs.

It follows that production costs are unlikely to be uniform, or nearly so, over all producers in a given market, as would need to be the case to transform competitive pricing into progressively-redistributive pricing (i.e., markets are unlikely to look much like Figure 4). ${ }^{68}$ Some sellers - the marginal sellers - will have high costs and others - the inframarginal sellers - will have low costs, and so the competitive price, which is determined by the costs of the marginal sellers, will be above the costs of the inframarginal sellers, ensuring that these sellers take a potentially large share of the surplus (Figure 5). ${ }^{69}$

Antimonopolism might push prices down from monopoly levels to competitive levels, and that might redistribute a substantial amount of surplus from sellers to buyers, but even were antimonopolism to be completely successful in creating perfectly competitive markets-itself a highly unlikely proposition-sellers would continue to command a share of the surplus, one that is potentially large. ${ }^{70}$ The amount of surplus going to sellers would be all the larger because competitive pricing maximizes the total surplus created by markets, leaving more surplus available for sellers to appropriate. If sellers are on average richer than buyers, then every bit of surplus they appropriate makes them richer, and potentially much richer if costs vary a great deal more than demand. Robert Hale, probably the greatest of the original progressive lawyer-economists, put it thus:

With the growth of trusts, there was some complaint of exorbitant charges, but the remedy which first suggested itself was, not direct regulation of the prices, but the

\footnotetext{
67 See Sam Peltzman, The Gains and Losses from Industrial Concentration, 20 J.L. \& ECON. 229, 231-33 (1977).

${ }^{68}$ See id.

${ }^{69}$ See id.

70 See HALE, supra note 5, at 25-26, 401; FRIED, supra note 6, at 114 ("[E]ven in situations of competition, whenever supply could not be expanded at constant costs, the 'owners of the superior resources' in the form of land or capital equipment acquired for lower than reproduction cost - so-called 'inframarginal producers'-would realize a surplus return ['economic rent'] in excess of costs.").
} 
enactment of anti-trust laws designed to restore free competitive conditions. . . . Even the classical economists realized . . . competition would not keep the price at a level with the cost of all the output, but would result in a price equal to the cost of the marginal portion of the output. Those who produce at lower costs because they own superior [capital] would reap a differential advantage which Ricardo, in his well-known analysis, designated "economic rent.",

The problem of scarcity in relation to monopoly, as it was understood by progressives a century ago, is reflected in Figure 6.

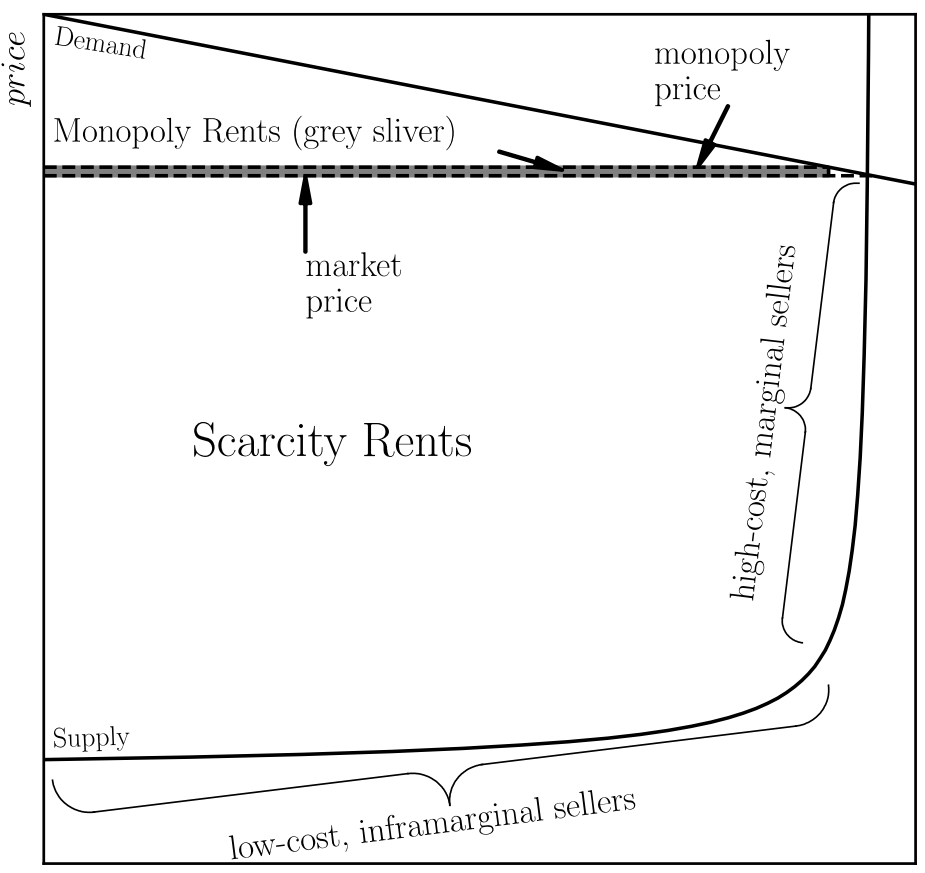

quantity

Figure 6

${ }^{71}$ HALE, supra note 5, at 25-26, 401. 
c. Monopoly Power and Scarcity Power Distinguished

\section{i. Scarcity Power}

The power associated with scarcity is in an important sense indistinguishable from that associated with monopoly. Both are founded on an excess of demand relative to supply. In situations of scarcity, the reason the low-cost, inframarginal sellers are able to charge the same price as the high-cost, marginal sellers (and therefore to extract surplus for themselves) is that there are more buyers willing to pay the price necessary to cover the cost of the high-cost sellers than there are low-cost units available for sale. A low-cost seller can, therefore, refuse to sell to any buyer who insists on a lower price, secure in the knowledge that there is another buyer out there whose only option is to buy from a high-cost seller and who therefore would be just as willing to buy from the low-cost seller at the high-cost price (Figure 7, in which for simplicity sellers are represented as having only two possible costs).

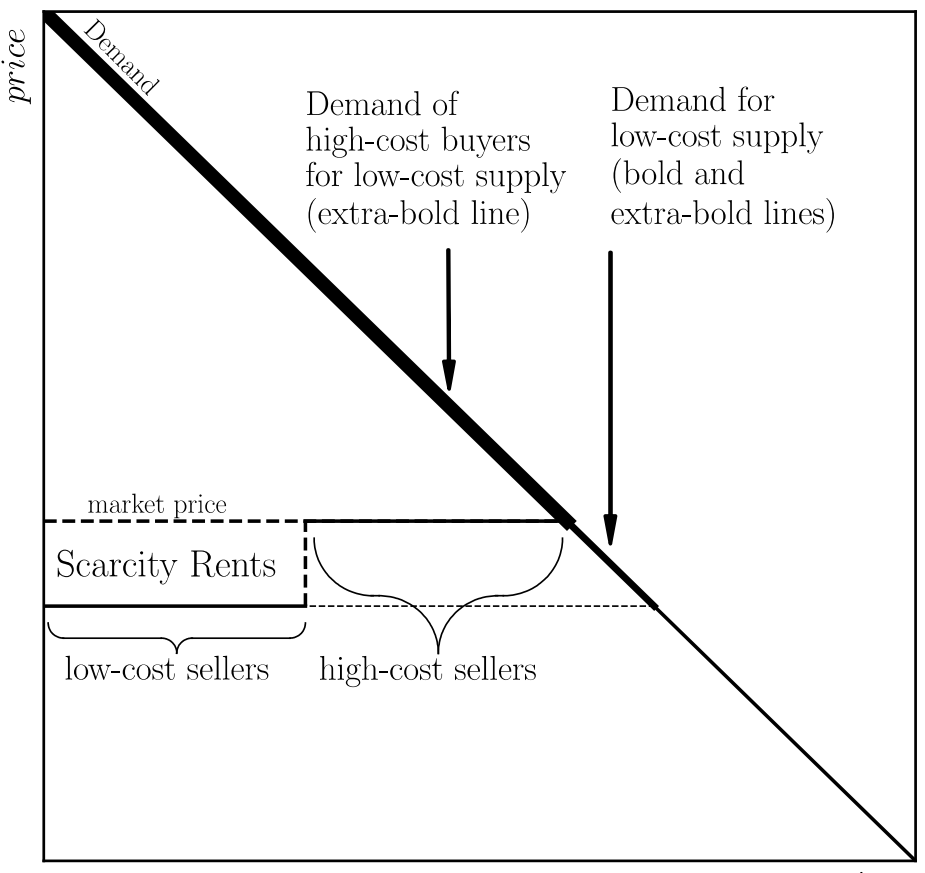

quantity

Figure 7 
Without this imbalance of demand and supply, which is baked into the concept of scarcity, there would be no reason for which inframarginal sellers could charge the same price as the price charged by the marginal sellers. The price line in Figure 6 (or indeed that in Figure 7) could sag down to the level of the supply curve at every point except the point at which the marginal buyer and seller transact, for only at that latter point is a price equal to the marginal seller's high costs necessary for a seller to be willing to sell.

The price line is kept uniform in competitive markets only because scarcity in a competitive market implies that there must be more willing buyers than willing sellers with respect to the low-cost production. Indeed, if the market is not competitive, and there is, for example, a single monopoly buyer, then the price line will sag: that buyer would insist on a price below the price at which the marginal seller would transact, and the inframarginal sellers would have to accept, because they could no longer be sure to find some other buyer willing to pay a price equal to the price at which the marginal seller would transact. Scarcity power derives from an excess of demand over supply that exists only when markets are fully competitive.

It is for this reason that personalized pricing-price discrimination-is impossible in competitive markets. A price line that sags represents a series of prices personalized to the cost of production of each unit of outputhigher prices for units that are costly to produce and lower prices for units that are cheaper to produce. But in a competitive market, the price line cannot sag down to take account of the lower costs of those who control scarce resources, because competition between the buyers who would like to make the line sag enables all sellers, even those who have cost advantages due to control over scarce resources, to insist upon the same price. Thus personalized pricing is no solution to the problem of scarcity power in competitive markets. Personalized pricing is, instead, entirely a creature of monopolized markets in which agents can dictate prices. ${ }^{72}$

The nature of scarcity-based power is starkest in the extreme case in which a resource is so scarce that there are no high-cost sellers in the market at all and supply of the low-cost product is simply insufficient to meet the demand that would exist were the product priced at cost. ${ }^{73}$ In this case, demand obviously exceeds supply and any seller can insist on the price that rations access to the good to the buyers with the highest

\footnotetext{
${ }^{72}$ See Woodcock, Big Data, Price Discrimination, and Antitrust, supra note 43, at 1386.

${ }^{73}$ See Ramsi A. Woodcock, Toward a Per Se Rule against Price Gouging, CPI ANTITRUST CHRON. (Sep. 2020), at 51-52 (discussing this sort of scarcity when it arises from unexpected surges in demand).
} 
willingness to pay. ${ }^{74}$ In particular, any seller can insist on a price equal to the value placed on the good by the marginal buyer-here the buyer who places the lowest value on the good of any buyer in the high-willingness-topay group of rationed buyers. The seller can reject any offer below that buyer's value, secure in the knowledge that there exist other buyers who place at least that value on the good and so are willing to pay that price (Figure 8).

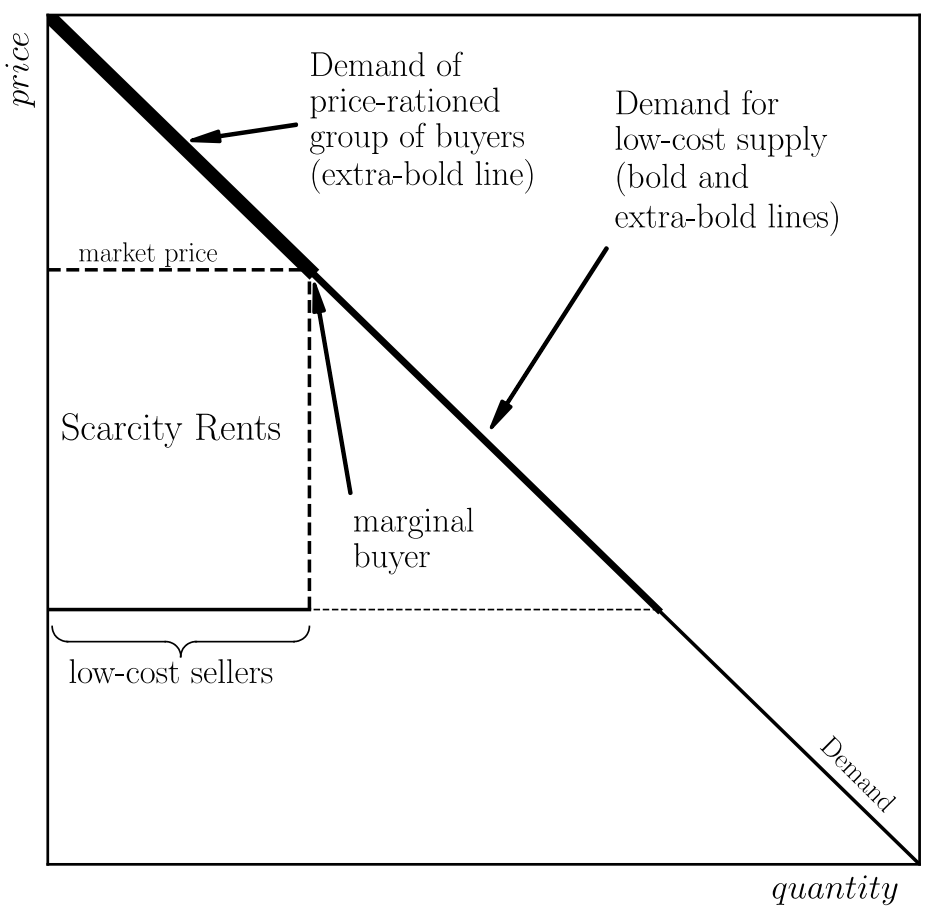

Figure 8

In such cases, in other words, the absence of high-cost sellers and the insufficiency of low-cost supply mean that the alternative faced by buyers to doing a deal with a low-cost seller is to do no deal at all, in which case buyers lose the value they place on the product. The marginal buyer who fails to acquire the good is willing to pay a price for the good equal to the marginal buyer's loss in value from not doing a deal, and so any seller can insist on a price from any buyer equal to that value lost by the marginal buyer, for otherwise the seller can simply sell to the marginal buyer at that

74 See id. (discussing this sort of scarcity when it arises from unexpected surges in demand). 
price.

\section{ii. Monopoly Power}

The monopolist's power is identical to a seller's scarcity-based power to insist on above-cost (and so surplus appropriating) prices, but for one important difference: the monopolist creates the scarcity-it is artificialwhereas the seller with scarcity-based power strives to eliminate the scarcity. ${ }^{75}$

Consider a seller that initially has power due to the presence of highercost producers in the market, as described the previous section. At this stage, the seller has every incentive to expand the seller's (low-cost) production because competition from high-cost sellers prevents our lowcost seller from raising price above the price at which the high-cost sellers sell their products. ${ }^{76}$ With price increases ruled out, our seller's only means of increasing profits is through increasing market share, for each additional unit the seller vends earns the seller the difference between the price of the good (competed down to the costs of the high-cost seller) and our low-cost seller's own lower costs (Figure 7). ${ }^{77}$ The seller's power here to earn rents is due to natural, not artificial scarcity and we would say that the seller has (natural) scarcity-based power but not monopoly power; the seller profits not by restricting output but by expanding it. ${ }^{78}$

As the low-cost seller takes market share from high-cost sellers, perhaps by selling at a price slightly below that at which the high-cost sellers are able to do business, the high-cost sellers exit the market until the low-cost seller is alone there. ${ }^{79}$ Only at this point does monopoly power spring into existence. For only now does the seller face a choice regarding whether to increase output beyond the level of output that prevailed when high-cost sellers remained in the market and up to the level required to satisfy the excess demand that exists for the low-cost version of the product at a price equal to that lower cost. That excess demand could not be satisfied when low-cost units were scarce and price was necessarily equal to the higher costs of marginal sellers, even under perfect competition. But by expanding output, the low-cost seller has eliminated the scarcity of low-cost production. The seller can increase low-cost production further, increasing

\footnotetext{
${ }^{75}$ See Teece \& Coleman, supra note 2, at 819-22; $c f$. FRIED, supra note 6, at 25 (describing "monopoly rents" as those "in which scarcity value [is] attributable to a naturally or artificially constrained number of producers").

${ }^{76}$ Cf. Peltzman, supra note 67, at 231-33.

${ }^{77}$ Cf. id.

${ }^{78}$ See Teece \& Coleman, supra note 2, at 819-22; cf. Peltzman, supra note 67, at 231-33.

${ }^{79}$ Cf. Peltzman, supra note 67, at 231-33.
} 
the size of the market, and reducing prices down toward the firm's lower cost of production, in order to satisfy buyers who are willing to pay more than the low production cost but who were not willing to pay the cost of the high-cost sellers when they were still in the market (Figure 9).

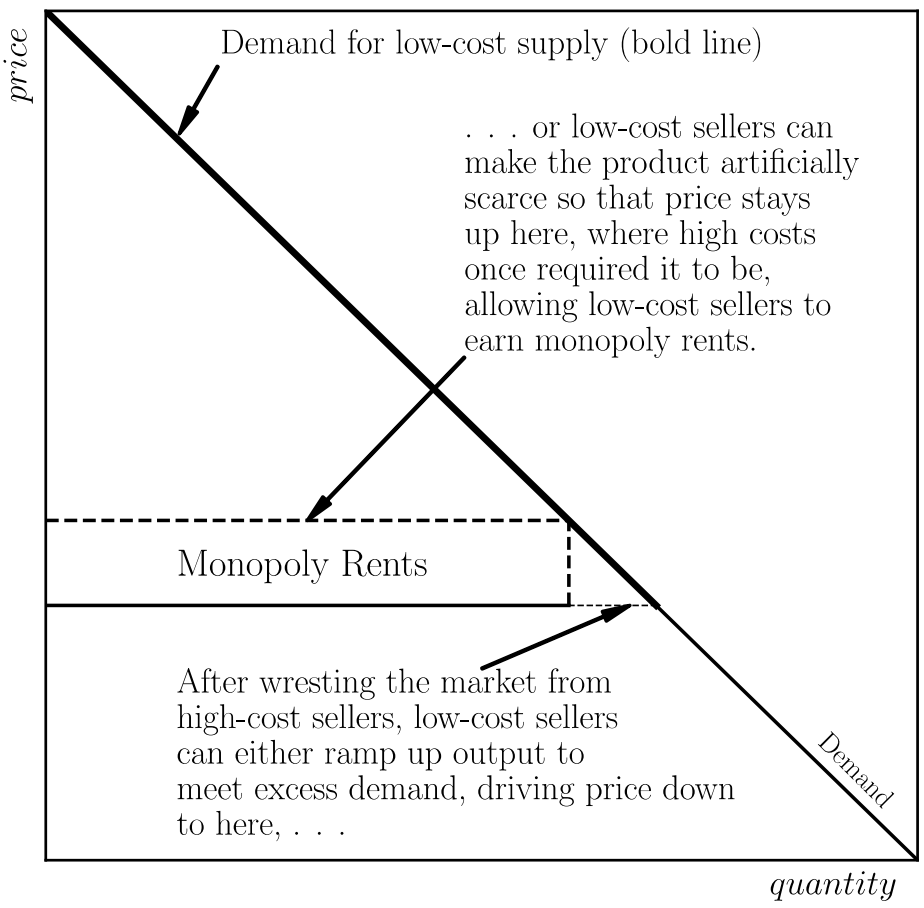

Figure 9

Some amount of output increase may in fact be profitable for the lowcost seller; that depends upon whether the costs of the high-cost sellers were so high that they drove prices above the profit-maximizing price for a seller with low costs. But it will never be profitable for our low-cost seller to increase output to levels that would satisfy all of the excess demand, because that would drive price down to the seller's production costs, eliminating all of the seller's profits. The seller will instead choose output to maximize profits, meaning that the low-cost seller will create artificial scarcity, transforming itself into a practicing monopolist. Our newly-minted monopolist will create a market that looks just like the market described in Figure 8, in which there is demand in excess of supply for a good for which there are no high-cost alternatives. Indeed, Figure 8 and Figure 9 are really the same picture. Only now the reason for which there are no high-cost 
alternatives will not be that the product is naturally scarce-that there is nothing that either the low-cost seller or high-cost sellers can do to make more-but will instead be that our low-cost seller has chosen not to make more low-cost products and high-cost sellers dare not return to the market because the low-cost seller can underprice them and take whatever business they wish to acquire. ${ }^{80}$ The low-cost seller's power to charge above-cost prices is here due to an artificial scarcity created by the low-cost seller, not to a natural scarcity associated with the inability of the low-cost seller to increase output in the short run. ${ }^{81}$

Both scarcity power and monopoly power are vulnerable to dynamic competition, which is competition from sellers that have found a way to produce at even lower cost. ${ }^{82}$ Such a dynamic competitor may have chanced upon a new supply of a scarce natural resource, or, thanks to research and development, may have overcome a technological barrier to production that the low-cost seller has failed to conquer. ${ }^{83}$ If dynamic competitors enter the market, the cycle repeats: the market returns to one in which there are low-cost and high-cost sellers, only now the original lowcost seller becomes a high-cost seller in this new market and the dynamic competitor is now the low-cost seller seeking to run high-cost sellers out of the market. If this disruption occurs when our original low-cost seller is enjoying monopoly power (i.e., after our original low-cost seller has driven the high-cost sellers from the market), then our original low-cost seller will no longer be able artificially to limit supply because buyers will simply buy from the new even-lower-cost dynamic competitor. Thus dynamic competition destroys the monopoly power acquired by our original low-cost seller (Figure 10).

${ }^{80}$ See F. M Scherer \& DAVID Ross, Industrial MARKET STRUCTURE AND ECONOMIC PERFORMANCE (3d ed. 1990).

${ }^{81}$ See Teece \& Coleman, supra note 2, at 819-22.

${ }^{82}$ See J. Gregory Sidak \& David J. Teece, Dynamic Competition in Antitrust Law, 5 J. COMPETITION L. ECON. 581, 603-7 (2009).

${ }^{83}$ Cf. id. 


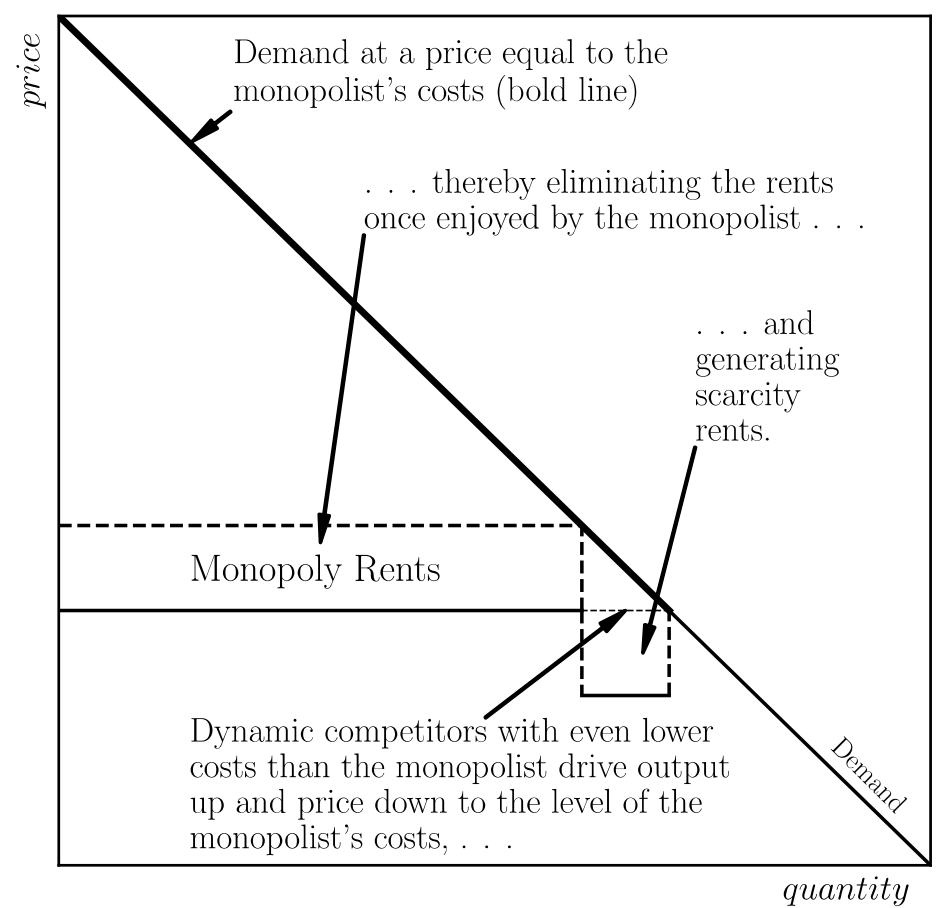

Figure 10

If this disruption occurs before our original low-cost seller has become a monopolist (i.e., before our original low-cost seller has driven the highcost sellers from the market), then the dynamic competitor earns scarcity rents of its own, and those will be larger, on a per unit-basis, than those enjoyed by our original low-cost seller, because the dynamic competitor will have even lower costs (Figure 11). 


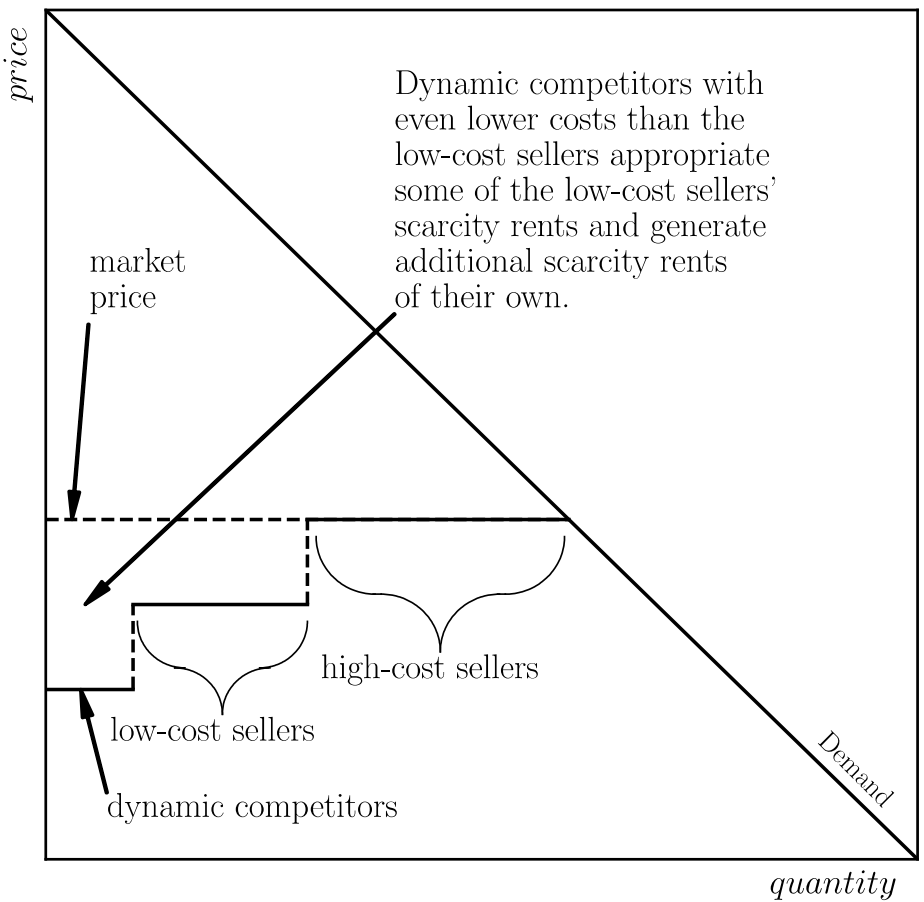

Figure 11

What is more, once either the dynamic competitor or our original low-cost seller has taken market share from the high-cost sellers, driving them from the market, the cost of the marginal unit will fall to the level of our original low-cost seller's low costs and competition between our original low-cost seller and the dynamic competitor will push price down to our original lowcost seller's costs. Our original low-cost seller's products will no longer play the role of the scarce, relatively-desirable products offered by the market. That role will now be played by the products sold by the dynamic competitor at even lower cost, explaining why competition is able to push price down and eliminate our original low-cost seller's scarcity rents.

It is evident that dynamic competition does not, therefore, destroy scarcity power in the way that it destroys monopoly power, but instead merely changes the identity of the firm that wields scarcity power, substituting the dynamic competitor for the original low-cost seller as scarcity rentier. The effects of dynamic competition are nonetheless good for consumers in both cases, because whether dynamic competition attacks monopoly power or scarcity power, dynamic competition reduces prices, and does so even though, in the scarcity case, it cannot eliminate scarcitybased power. 
This point is worth repeating. While dynamic competition can eliminate monopoly rents in that it can make artificial scarcity impossible, dynamic competition can never eliminate scarcity. ${ }^{84}$ The agents of competitionnew firms with lower costs - bring competition to the market by bringing scarcity to the market. They beat out incumbents by lowering costs in ways that incumbents are unable to do. Thus competition eliminates scarcitybased power only in the sense of transferring it to new agents, whereas competition eliminates monopoly power entirely by preventing any one firm from enjoying a cost advantage for so long that it is able to drive all competitors from the market. Given the power of competition to snuff out monopoly, firms naturally try to slow competition, and the purpose of the antitrust laws is to prevent such behavior. ${ }^{85}$ In promoting competition, the antitrust laws seek, in other words, to ensure that the only form of power in markets is scarcity power, not monopoly power.

\section{d. The Generality of the Critique}

The foregoing account of the origins of scarcity and monopoly rents may appear to apply only to markets in which economic growth takes place through cost reductions - otherwise known a process innovation — as in the

\footnotetext{
${ }^{84}$ To argue that scarcity power is an inherent part of competition is not to argue that the proceeds of that power-the scarcity rents-much less monopoly rents, are in any sense necessary to finance competition, to reward successful competitors, or otherwise to bring about the efficient operation of a market economy. $C f$. JOSEPH A. SCHUMPETER, CAPITALISM, SOCIALISM AND DEMOCRACY 105 (1950) (arguing that monopoly profits are necessary to finance innovation); Verizon Commc'ns Inc. v. Law Offices of Curtis $V$. Trinko, 540 U.S. 398, 407 (2004) ("The opportunity to charge monopoly prices - at least for a short period - is what attracts 'business acumen' in the first place; it induces risk taking that produces innovation and economic growth. To safeguard the incentive to innovate, the possession of monopoly power will not be found unlawful unless it is accompanied by an element of anticompetitive conduct."). Rents are, by definition, not necessary to induce firms to produce and compete at optimal levels. See Woodcock, The Antitrust Case for Consumer Primacy in Corporate Governance, supra note 43, at 141226. The scarcity-based power to extract rents from buyers cannot be eliminated, but government can intervene to prevent the exercise of that power by, for example, dictating prices, taxing away the rents extracted through bargaining, or weakening the ability of sellers to withhold access to their goods to buyers who refuse to pay full price for them. Each of these interventions will have an efficiency cost, but this cost is essentially administrative. It arises from the difficulty of identifying rents and enforcing their redistribution, not from the bare fact of their redistribution itself, for rents are, again, by definition, income not necessary to induce efficient behavior by firms. For more on taxation and rate regulation, see infra Section III.A. For more on weakening the ability of sellers to withhold access, see Kennedy, supra note 13, at 30-33.

${ }^{85}$ See Richard A PoSNER, ANTITRUST LAW (2d ed. 2001).
} 
case of the high-cost and low-cost sellers just described. ${ }^{86}$ But in fact the account applies with great generality to all markets, including those for which growth typically takes place through the improvement of products rather than the reduction of costs. ${ }^{87}$ That is because what really matters to buyers and sellers in any market is only the surplus created by the market transactions in which they engage, and that is determined by the excess of buyer value over seller cost. It follows that product improvements can be modeled as cost reductions without changing the results of the analysis by measuring the surplus created by the product improvement and then reproducing that amount through a cost reduction with buyer value held constant. ${ }^{88}$ Thus we can apply the supply and demand lines in Figure 2 to any differentiated-product market - as markets in which growth takes place through product improvements are known-so long as the space between the lines, which represents the surplus created by the market, accurately represents the excess of value over cost for the differentiated products involved. ${ }^{89}$

Once the generality of this account is understood, it becomes clear that what is often called "Schumpeterian rent" is really just a kind of scarcity rent, and has therefore already been fully addressed by this account. ${ }^{90}$ Schumpeterian rent is due to the power that comes from introducing into a market a technological advance that competitors are temporarily unable to reproduce. ${ }^{91}$ It is, therefore, no more than the proceeds of the power enjoyed by the dynamic competitor that brings lower-cost production to a market and is able to earn scarcity rents thereby, until the next dynamic competitor with even lower costs comes along. Schumpeterian rent differs from scarcity rent more generally only in that Schumpeterian rent is defined to be short-lived. ${ }^{92}$ A technological advance that no further dynamic competitor can reproduce over a long period of time, or the natural resource constraint that technology is not able to overcome for decades, are examples of scarcity that is not Schumpeterian in character because it is

\footnotetext{
86 See FRIED, supra note 6, at 26 (treating product differentiation and monopolistic competition as different in kind from the perfectly competitive markets considered by the original progressives).

${ }^{87}$ See Frederic M. Scherer, First Mover Advantages and Optimal Patent Protection, $40 \mathrm{~J}$. TECH. TRANSFER 559, 562-65 (2015).

${ }^{88}$ This is the analogue of the quality-adjusted price concept, applied here to adjust surplus, rather than price. See Keith Cowling \& A. J. Rayner, Price, Quality, and Market Share, 78 J. POL. ECON. 1292, 1294 (1970).

${ }^{89}$ See Edward Hastings Chamberlin, The TheOry OF MONOPOlistic Competition: A RE-ORIENTATION OF THE THEORY OF VALUE 71 (7th ed. 1956).

${ }^{90}$ See Teece \& Coleman, supra note 2, at 820-22.

${ }^{91}$ See id.

92 See id.
} 
long-lived..$^{93}$ The historical transition of Western economies from markets characterized by short-lived Schumpeterian rents to economies characterized by long-lived scarcity rents plays an important role in the contemporary left critique of antimonopolism, as we shall see shortly. ${ }^{94}$ But, for the original progressives of a century ago, it was enough to critique antimonopolism by pointing out that scarcity is an inherent feature of competition, and so the inequality created by scarcity rents of all kinds, Schumpeterian or otherwise, can never be touched by a pure antimonopoly policy. $^{95}$

\section{e. The Original Progressive Recipe for Inequality}

That was not to say, however, that scarcity rents could not be touched by anything. Indeed, sellers with low costs are not actually required to use their scarcity-based power to charge above-cost prices and appropriate surplus. ${ }^{96}$ Costs in the economic sense are, by definition, all costs, including a reasonable return on investment, required to make a seller ready, willing, and able to sell whatever level of output is demanded by the market. ${ }^{97}$ It follows that, if they wish to do so, sellers can choose to charge at-cost prices-prices that leave all of the surplus generated by the market to buyers - and still find it in their interests to remain in the market and continue to generate that surplus for others. ${ }^{98}$ Sellers do not actually charge at-cost prices only because they like profit, not because they need it in any economically meaningful sense. ${ }^{99}$

It also follows from the definition of economic cost that government can force sellers to charge at-cost prices, or can extract from sellers, via taxation, whatever surplus sellers do earn from charging above-cost prices and repurpose it to other uses, without reducing sellers' output (Figure 12).

\footnotetext{
${ }^{93}$ See id.

${ }^{94}$ See infra Section II.B.2.

95 See HALE, supra note 5, at 25-26, 401.

96 See Ramsi A. Woodcock, The Antitrust Duty to Charge Low Prices, 39 CARdozo L. REV. 1741, 1753 (2018).

97 See Woodcock, The Antitrust Case for Consumer Primacy in Corporate Governance, supra note 43 , at $1412-26$.

98 See id.

${ }^{99}$ See id.
} 


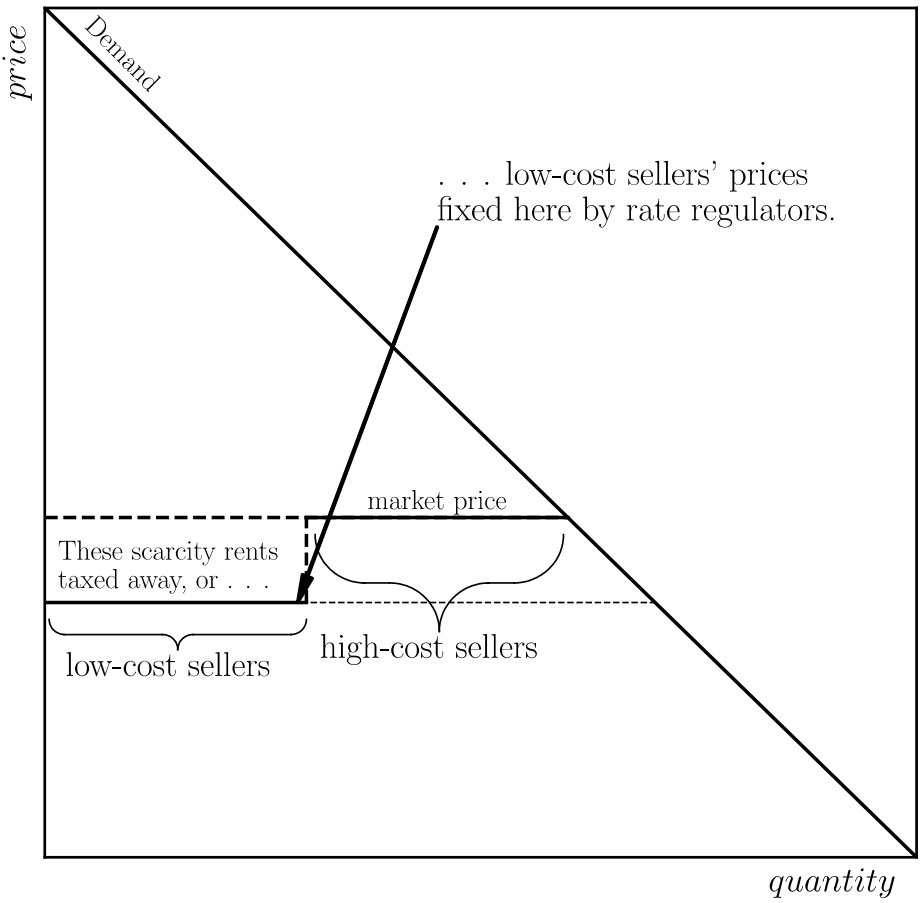

Figure 12

The progressives who recognized competition's limitations a century ago understood this and therefore turned to rate regulation and taxation as alternative means of addressing the problem of inequality. ${ }^{100}$ They pressed for regulation of prices in industries such as urban residential leasing in which scarcity was thought to be most enduring, in addition to pushing for price regulation in public utility industries characterized by massive economies of scale, for which latter the principal concern is monopoly power. ${ }^{101}$ Progressives also pushed for income taxation and, notably, corporate taxation, which tends to fall on scarcity rents directly because of deductions for interest on investment financing. ${ }^{102}$ The answer to Richard Hofstadter's famous question- "what happened to the antitrust movement?"- was that progressives came to understand that what mattered were competition-immune (or, more to the point, competition-created) scarcity rents; and so taxation, and that special form of taxation for which buyers keep the proceeds that is known as price regulation, became

100 See FRIED, supra note 6, at 40, 68, 160-205; Avi-Yonah, supra note 6, at 1212-31.

101 See FRIED, supra note 6, at 124, 195-96, 204.

102 See Reuven Avi-Yonah, A New Corporate Tax, TAx Notes FedERAL 653, 655-59

(2020); Avi-Yonah, supra note 6, at 1212-31; FRIED, supra note 6, at 203. 
progressives' preferred tool to address inequality. ${ }^{103}$

It is also worth noting that although progressive ardor for antitrust cooled early on, that did not prevent antitrust in America from institutionalizing itself and growing in power during the Postwar period. ${ }^{104}$ During that period, antitrust exhibited a tendency that one finds as well in antimonopolism today: a desire to go beyond the remediation of monopoly rents in particular to try to deploy antitrust remedies to attack scarcity rents. This was epitomized by the attempt in the 1970s of the American antitrust establishment to create a "no-fault" monopolization regime, meaning a regime that would have prohibited the earning of economic profits even when a seller has not taken steps to block competition. ${ }^{105}$ That would of course have swept in sellers that earn economic profits due to scarcity rather than monopoly.

The Chicago School nipped this tendency in the bud by pointing out that breaking up sellers that earn scarcity rents risks destroying whatever scarce resources - whether natural, technological, or experiential-make it possible for sellers to produce at lower cost and so to benefit from scarcity, or at least risks preventing firms with lower costs from increasing market share and spreading lower-cost production across the market as fast as possible. ${ }^{106}$ Chicago argued that the solution to scarcity is the creation of more scarcity, in the sense of new firms with even lower costs. ${ }^{107}$ It is not, argued Chicago, the breakup of existing low-cost sellers, for that merely risks increasing their costs. ${ }^{108}$ One of the original progressives might well have added that such cost increases would be particularly unfortunate because they destroy surpluses that the government might otherwise tax away from sellers and put to good use. Chicago and the original progressives might well have agreed that only firms that have artificially created the scarcity from which they benefit can be punished without risk of raising costs, and then only by targeting the behaviors they use to

103 See Richard Hofstadter, What Happened to the Antitrust Movement?, in THE PARANOID STYLE IN AMERICAN POLITICS AND OTHER ESSAYS 188 (1st ed. 1967); FRIED, supra note 6, at 24-25, 40, 68, 160-205; Avi-Yonah, supra note 6, at 1212-31.

104 See Hofstadter, supra note 103; JOHN KENNETH GALBRAITH, THE NEW INDUSTRIAL STATE (2015).

105 See Note, The Industrial Reorganization Act: An Antitrust Proposal to Restructure the American Economy, 73 Colum. L. REV. 635, 637-40 (1973); Herbert Hovenkamp, The Neal Report and the Crisis in Antitrust, No. ID 1348707, 1-5 (2009).

106 See Harold Demsetz, Two Systems of Belief About Monopoly, in INDUSTRIAL Concentration: The New Learning 164 (Harvey J. Goldschmid et al. eds., 1974). Recall that firms that have scarcity power in a competitive market have an incentive to increase market share because they cannot raise prices. See supra Section II.B.1.c.

107 See id.

${ }^{108}$ See Peltzman, supra note 67, at 262. 
undermine competition, rather than by breaking them up. ${ }^{109}$

There intellectual matters stood until Thomas Piketty updated the original progressives' emphasis on taxation and Chicago's appreciation for the importance of scarcity and embedded them in a compelling historical account of inequality, one that again rejects antimonopolism as a redistributive vehicle. ${ }^{110}$

\section{Piketty's Implicit Critique of Antimonopolism}

The second, contemporary, left critique of antimonopolism, which is due, somewhat implicitly, to Thomas Piketty, builds on the original progressive insights regarding scarcity, but updates them with a dynamic story that explains the resurgence of wealth inequality over the past fifty years.

It is probably fair to say that Piketty's book, Capitalism in the TwentyFirst Century, brought contemporary intellectual interest in wealth inequality into focus. ${ }^{111}$ The book did this not only by presenting the results of Piketty's painstakingly-collected data on the growth of wealth inequality since World War Two-data that established incontrovertibly that inequality has greatly increased in recent decades - but also by providing a theoretical account of how that inequality came into being and why it will continue to grow. ${ }^{112}$ The theory is usually summarized by Piketty's conclusion that " $r>g$ ": the rate of return on capital in the long run is greater than the rate of growth of the economy. ${ }^{113}$ The implication is that owners' share of the economic pie always ultimately grows faster than the pie itself, ensuring that in the long run the share of the pie going to labor will shrink and inequality will increase. ${ }^{114}$

Scarcity is the ultimate content of Piketty's contention that historically the rate of return on capital has been about four of five percent and is likely to stay that way. That return might count as cost, in the sense that it might be necessary to make the owners of capital ready, willing, and able to supply it, in which case it would not count as scarcity rent. ${ }^{115}$ But Piketty

\footnotetext{
109 See POSNER, supra note 85.

110 See PIKETTY, supra note 3, at 573.

111 See PIKETTY, supra note 3; Idrees Kahloon, Thomas Piketty Goes Global, THE NEW YORKER, https://www.newyorker.com/magazine/2020/03/09/thomas-piketty-goes-global (last visited May 31, 2021).

112 See PIKETTY, supra note 3, at 1-49.

113 See id. at 442-51.

114 See id. at 443.

115 See Woodcock, The Antitrust Case for Consumer Primacy in Corporate Governance, supra note 43 , at $1412-26$.
} 
does not see the return on capital as cost. Indeed, he makes clear that if part of his four or five percent figure for the rate of return were shown to be cost, he would deduct that part in order to determine the true rate of return. He accepts, for example, that landowners might incur costs in developing their land and that such costs should be deducted from the four or five percent figure for the rate of return, leading to a revised rate of two or three percent. ${ }^{116}$ It follows that Piketty sees the return on capital as economic profit in the sense of a return not necessary to induce owners to supply their capital. ${ }^{117}$

Economic profits can, of course, be due either to monopoly power or scarcity power. ${ }^{118}$ But Piketty flatly rejects the notion that monopoly power plays sufficient role in juicing the rate of return on capital as to make competition policy sufficient to reduce inequality. ${ }^{119}$ According to Piketty, "pure and perfect competition cannot alter the inequality $r>g$, which is not the consequence of any market 'imperfection." 120 It follows that Piketty sees the economic profits represented by his four or five percent return figure as scarcity rents.

Piketty does appear at one point to distinguish his return on capital from scarcity rents. He writes that scarcity magnifies the return on capital, suggesting that the return itself is not driven by scarcity. ${ }^{121}$ And he argues that the return on capital is in a sense normal: capital needs to be paid something, and that something just happens to be a high four or five percent. ${ }^{122}$ But this distinction between scarcity as a booster of returns and a normal rate of return is not really tenable from the perspective of our

\footnotetext{
116 See Piketty, supra note 3, at 445 ("Even if we accept a much lower estimate of the pure yield on capital--for example, by accepting the argument that many landowners have made over the years that it is no simple matter to manage a large estate, so that this return actually reflects a just compensation for the highly skilled labor contributed by the owner-we would still be left with a minimum [and to my mind unrealistic and much too low] return on capital of at least 2-3 percent a year, which is still much greater than [the] 0.1-0.2 percent [growth rate of the economy from antiquity through to the seventeenth century].").

117 See Woodcock, The Antitrust Case for Consumer Primacy in Corporate Governance, supra note 43, at 1412-26.

118 See supra Section II.B.1.c.

119 See Piketty, supra note 3, at 537 ("[T] he fact that capital yields income, which in accordance with the original meaning of the word we refer to in this book as 'annual rent produced by capital,' has absolutely nothing to do with the problem of imperfect competition or monopoly.").

${ }^{120}$ See PIKETTY, supra note 1 , at 537.

121 See PIKETTY, supra note 3, at 35 (arguing that the factors pushing up the rate of return on capital "can be aggravated by the Ricardian scarcity principle: the high price of real estate or petroleum may contribute to structural divergence").

122 See $i d$. at 536 ("If capital plays a useful role in the process of production, it is natural that it should be paid.").
} 
definition of economic profit as payments in excess of amounts necessary to induce productive activity. ${ }^{123}$ The only reason capital can earn any return at all in the sense of economic profit, assuming, as Piketty does, that this return is not comprised entirely of monopoly profit, is scarcity: the fact that some sellers have lower costs than others and so control scarce resources. ${ }^{124}$ It follows that Piketty's four or five percent return is a scarcity rent and that what Piketty means by "scarcity" is extreme scarcity: markets for which the marginal buyer pays a price in excess of the cost of production of the marginal unit, because resources are so scarce that there is simply no production-not even high-cost production-available to satisfy demand. Piketty's scarcity is the extreme scarcity of Figure 8 and his return on capital is the less-extreme scarcity of Figure 7.

From this perspective, we can restate, as follows, Piketty's thesis that inequality will grow in the long term because the rate of return on capital exceeds the growth rate of the economy. ${ }^{125}$ Piketty in effect argues that if national income (i.e., Picketty's $g$ ) is growing at a faster rate than are economic profits (i.e., Piketty's return on capital, $r$ ), and we can assume that surplus grows at the same rate as national income (that is, diminishing returns have not set in), then surplus, too, must be growing faster than are economic profits. As a result, the very rich, for whom income is assumed to come primarily from economic profits, will be losing ground to everyone else. But if economic profits are greater than increases in surplus-if $r>$ $g$ - then the rich, who as shareholders tend to enjoy the economic profits created by the economy, will pull away from everyone else. ${ }^{126}$

Thus, in the language of rents, one might say that Piketty's theory depends on the size of the economic profits generated by sellers. Because Piketty rejects the notion that these profits are due to monopoly power, he rejects the notion that $r$ can be driven down to $g$ and inequality eliminated simply through competition policy. ${ }^{127}$ Instead, he argues that only tax policy and other measures aimed at redistributing scarcity rents can drive $r$ down. ${ }^{128}$ Indeed, he argues that only two main factors have ever reduced scarcity rents historically, and then only once in the history of civilization, in the mid-twentieth century. ${ }^{129}$ The first is the world wars and the Great Depression, which in our schema would have reduced the amount of

\footnotetext{
123 See Woodcock, The Antitrust Case for Consumer Primacy in Corporate Governance, supra note 43 , at 1412-26.

${ }^{124}$ See infra Section II.B.1.c.

${ }^{125}$ See Piketty, supra note 3, at 442-51.

${ }^{126}$ See id.

${ }^{127}$ See id. at 536-37.

128 See id. at 597-746.

${ }^{129}$ See id. at 449.
} 
variation between low- and high-cost producers, wiping out all of the highest-quality and so lowest-cost assets, and so reducing the size of scarcity rents (i.e., transforming markets from that depicted in Figure 5 to that depicted in Figure 4). ${ }^{130}$ This factor does not lend itself to future use by policymakers to reduce inequality. The second is the institution of the income tax with high marginal rates on large incomes. ${ }^{131}$

In the final analysis, the source of inequality, in Piketty's view, is that the rich own all the best stuff and it is enough better to ensure that even in competitive markets they can negotiate enough in exchange for it to do better than the economy as a whole. In Piketty's view, Figure 6, with its depiction of large scarcity rents, is basically right. This is most obvious in the case of the very largest fortunes. Piketty notes that "[f]or the largest inherited fortunes, on the order of tens of billions of dollars or euros, one can probably assume that most of the money remains invested in the family firm (as is the case with the Bettencourt family with L'Oreal and the Walton family with Walmart in the United States." 132 The immense returns earned on these fortunes literally come from rents earned by a single business enterprise operating in a single market, loosely defined, just as Figure 6 depicts. L'Oréal and Walton heirs rake in surplus year after year, not because these companies are monopolies - there are lots of cosmetic companies out there, and Walmart's "everyday low prices" is hardly a monopolist's tagline_-but because these companies either occupy a market niche that no other firms are able to challenge or simply have lower costs than their competitors, which is to say, in both cases: because of scarcity.

Savvy investor Warren Buffett is another example. When he professes to look for firms with "moats" around them, he does not mean monopolies. ${ }^{133}$ He means firms that control scarce resources, such as rail networks. Given the high cost of putting down track, there will be no new entry into the rail network market in the United States anytime soon. And until then, Buffett, whose company Berkshire Hathaway purchased Burlington Northern Santa Fe railroad in 2010, will enjoy surpluses. ${ }^{134}$

But association of wealth with ownership of all the best stuff is also true for more middling fortunes, albeit for a slightly different reason. Piketty

\footnotetext{
${ }^{130}$ See id.

${ }^{131}$ See id.

${ }^{132}$ See id. at 559.

${ }^{133}$ See Tae Kim, Warren Buffett Believes this is "the Most Important Thing" to Find in a Business, CNBC, https://www.cnbc.com/2018/05/07/warren-buffett-believes-this-is-themost-important-thing-to-find-in-a-business.html (last visited May 18, 2021).

${ }^{134}$ See Patrick Morris, The Truth Behind Warren Buffett's Billion-Dollar Railroad Bet, THE MotLEY FOOL, https://www.fool.com/investing/general/2014/06/22/the-truth-behindwarren-buffetts-billion-dollar-ra.aspx (last visited May 18, 2021).
} 
argues that "as we move down the list [of the largest fortunes] it is likely that many inherited fortunes are held in diversified portfolios ...."135 But the diversified portfolios also tend to generate economic rents because, according to Piketty, they are large enough to enable their owners to afford superior investment advice - that is, to realize economies of scale in portfolio management-ensuring that the money is used to purchase the scarcest assets in the markets in which they are invested. ${ }^{136}$

The implication of Piketty's work is that antimonopolism misses the causes of contemporary inequality if it sticks to attacking true monopolies and, if it tries to use breakup to deal with scarcity, can only solve the problem in the way that Allied bombers did for Europe: by destroying enough capital so as to flatten the cost curve and drive down the rate of return on capital. Piketty therefore argues that the solution to inequality is taxation, rather than antimonopolism: government must tax away scarcity rents and distribute them broadly to the public. ${ }^{137}$

\section{EXPLAINING CONTEMPORARY AMERICAN PROGRESSIVE INTEREST IN REDISTRIBUTION THROUGH THE ANTITRUST LAWS}

\section{A. The Long March Around the Tax System in Legal Academia}

The fact that the progressives of a century ago and the intellectual godfather of contemporary interest in inequality reject the notion that inequality is due to monopoly rents poses the question why there is an antimonopoly movement in America today at all. The question is all the more interesting because the movement is not a product of the antitrust establishment, as was the mid-century push for a no-fault monopolization regime. ${ }^{138}$ That old establishment, which pushed antimonopolism because it was its professional duty to do so, is long gone, replaced by enforcers and antitrust professors who have absorbed enough of the Chicago School critique that they have been content to advocate for incremental, centrist change in enforcement. ${ }^{139}$ There are, it appears, two causes of the curious

\footnotetext{
${ }^{135}$ PIKETTY, supra note 3 , at 559.

${ }^{136}$ See id. at 571.

${ }^{137}$ See id. at 449.

138 See Hovenkamp, supra note 105, at 1-2; Kovacic, supra note 64, at 1119-1128,11371139.

139 See Hofstadter, supra note 103 (discussing the institutionalization of antitrust); How THE CHICAGo SCHOOL Overshot THE MARK (Robert Pitofsky ed., 2008) (collection of work reflecting the new center-left establishment); Jonathan B. Baker, Economics and Politics: Perspectives on the Goals and Future of Antitrust, 81 FordHAM L. REV. 2175, 2184 (2012) (articulating the contemporary center-left view of enforcement).
} 
resurgence of antimonopolism, one a long-term condition and the other a recent triggering factor.

The long-term condition is the American tax revolt that started in the 1980 s with cuts by the Reagan administration to the highest marginal income tax rates, and has continued more or less unabated to the present day, the rising tide of inequality, and bipartisan popular concern about it, notwithstanding. ${ }^{140}$ Despite efforts by Democratic presidents to raise them, rates remain a fraction of what they were before Reagan. ${ }^{141}$ Even the Biden administration, which has proposed the most ambitious taxation and spending programs in decades, has not proposed raising income tax rates back to where they once were. ${ }^{142}$ Once it became clear in the 1980 s that voters were no longer supportive of the use of the tax system to redistribute wealth, progressive scholars started to show interest in alternative redistributive schemes that had been considered, and eventually rejected, by the original progressives and which have now also been rejected again by Piketty. ${ }^{143}$ Contemporary antimonopolism is an expression of this continuing urge to redistribute around the political barrier of tax policy.

Much of the literature that has emerged from this desire to avoid politically infeasible broad-based tax policy - a literature that continues to grow by leaps and bounds-focuses on rejecting an argument that had developed, ironically, out of progressive fervor for redistribution through taxation and reached its highest form almost on the eve of the Reagan era tax revolt. ${ }^{144}$ That was the argument against redistribution at the market level and in favor of the income tax. ${ }^{145}$ It had started in earnest with Harold

140 See BROWNLEE, supra note 7, at 182-83, 210-11, 228, 241, 272, 286; PIKETTY, supra note 3 , at 499.

141 See BROWNLEE, supra note 7, at 178-249; Historical Highest Marginal Income Tax Rates, TAX POL'Y CENTER, https://www.taxpolicycenter.org/statistics/historical-highestmarginal-income-tax-rates (last visited Jun. 2, 2021) (showing that the highest marginal income tax rate, which was $92 \%$ in 1953 , fell from $70 \%$ in 1980 to $50 \%$ in 1982 , has not risen above $39.6 \%$ since, and is currently $37 \%$ ).

${ }^{142}$ See United States Department of the Treasury, The Made in America Tax Plan, TAX POL'Y ECON. (2021).

${ }^{143}$ See Ramsi Woodcock, Making the Rich Pay More and the Poor Pay Less: Personalized Pricing as a Remedy in Antitrust and Public Utility Regulation, SSRN SCHOLARLY PAPER (Feb. 17, 2019), https://papers.ssrn.com/abstract=3378864.

${ }^{144}$ See, e.g., Anthony Atkinson \& Joseph Stiglitz, The Design of Tax Structure: Direct versus Indirect Taxation, 6 J. PuB. ECON. 55, 602 (1976); Harold Hotelling, The General Welfare in Relation to Problems of Taxation and of Railway and Utility Rates, 6 ECONOMETRICA 242, 242 (1938).

145 See F. Y. Edgeworth, The Pure Theory of Taxation III, 7 ECON. J. 550, 568 \& n.1 (1897) ("If a given amount . . . is raised by taxing a few commodities . . . there will in general occur under the head of those commodities a loss of 'consumers' rent' which does not occur when the amount is directly subtracted from income[.]"); Hotelling, supra note 
Hotelling in the 1930s and become the subject of a celebrated 1976 paper by two liberal lions of the economics world, Anthony Atkinson and Joseph Stiglitz. ${ }^{146}$ These authors were defending, against attempts at suffocation through half-measures, the great insight of the original progressives that redistribution could best be implemented only through taxation.

The sort of taxation that the original progressives had envisioned for scarcity rents was to be narrowly tailored to those inframarginal sellers in every market that had lower production costs than the marginal sellers and so could appropriate a share of the surplus for themselves. ${ }^{147}$ This may at first appear to involve taxing individual commodities - imposing a tax on oil, say, if oil companies seem to be earning large scarcity rents. But commodity taxation is in fact too blunt a tool, for it applies to all sellers, both inframarginal and marginal, low cost and high cost, with the result that such a tax would drive the marginal sellers from the market and effectively create artificial scarcity and hence inefficiency, rather than simply redistributing surplus as intended. ${ }^{148}$ The sort of taxation that the original progressives had envisioned was therefore much more narrowly targeted: it was meant to be personalized to each individual seller. ${ }^{149}$ Those that earned scarcity rents were to be taxed and those that did not, were not. ${ }^{150}$ In practice, of course, it would be almost impossible for government to distinguish the inframarginal sellers from the marginal sellers, because economic cost is a subtle concept. ${ }^{151}$ To tax away earnings above cost, one

144, at 242 (stating that "all taxes on commodities, including sales taxes, are more objectionable than taxes on incomes, inheritances, and the site value of land"); David Walker, The Direct-Indirect Tax Problem: Fifteen Years of Controversy, 10 PUB. FIN. I FinANCES PUBliQues 153 (1955); JOHN Richard Hicks, VAlue AND CAPITAL: AN INQUIRY INTO SOME FUNDAMENTAL PRINCIPLES OF ECONOMIC THEORY (2001) (“A tax on commodities lays a greater burden on consumers than an income tax."); Atkinson \& Stiglitz, supra note 144, at 74 ("If a general income tax function may be chosen by the government, we have shown that, where the utility function is separable between labor and all commodities, no indirect taxes need be employed."); A. B. Atkinson, Optimal Taxation and the Direct versus Indirect Tax Controversy, 10 THE CANADIAN JOURNAL OF ECONOMICS / REVUE CANADIENNE D'ECONOMIQUE 590, 602 (1977) ("We have not considered the administration of the two types of taxation, and the possibility that one may be more difficult to avoid or evade.").

146 See Hotelling, supra note 144, at 242; Atkinson \& Stiglitz, supra note 144, at 602; Atkinson, supra note 145, at 595. A somewhat different telling of the intellectual history that follows may be found in Woodcock, Making the Rich Pay More and the Poor Pay Less, supra note 143.

${ }^{147}$ See FRIED, supra note 6, at 201-2.

148 See id. at 202-3.

149 See id. at 201-2.

150 See id.

151 See id. at 202 ("[T]he problems of isolating that portion of rents that reflect 
must decide what expenditures made by a seller really are necessary to keep the seller in the market and what expenditures are not, and therefore count as taxable rents. ${ }^{152}$

Rather than give up, the original progressives turned to two workable proxies for scarcity rent. One was the taxation of some fraction of corporate profits net of interest payments-what has come to be known as the corporate tax. ${ }^{153}$ The idea here was that marginal sellers probably only earn enough revenues to pay off their loans, plus whatever additional return is required to attract equity investment. ${ }^{154}$ By allowing a deduction for interest, and also setting the corporate tax rate substantially below $100 \%$, corporate taxation would avoid taxing returns that marginal firms need to satisfy lenders and investors, but would still take a substantial chunk of the scarcity rents earned by the inframarginal firms. ${ }^{155}$ This one-size-fits all approach would not get at all of the scarcity rents, but it would get at some. And the rest, it was argued, could be sopped up through an additional tax applied directly to the rich people to whom all scarcity rents were ultimately paid, either as dividends to shareholders or as salaries to superstar managers. ${ }^{156}$ Such an income tax also would necessarily be imperfect, because the government would not be able to say for sure what part of an individual's income was really surplus that could be taxed away without causing the employer or investment paying the income to alter its hiring or capital acquisition decisions, and what part would cause firms to do without more labor or investment rather than bulk up payouts in order to compensate workers or investors for the tax. ${ }^{157}$ The hope was that by setting rates carefully, government could avoid such distortions. ${ }^{158}$

But could it? Atkinson and Stiglitz argued that, whatever the level of distortion that income taxation might cause, it was at least less in amount than the distortion caused by the alternative of commodity taxation. ${ }^{159}$ The controversy had more or less started out with an attempt by Harold Hotelling to answer the narrower question whether it is better to pay for infrastructure through general tax revenues drawn ultimately from "taxes on incomes, inheritances, and the site value of land," or through dedicated

inframarginal tastes for current consumption or leisure seem . . . intractable.").

152 See Woodcock, The Antitrust Case for Consumer Primacy in Corporate Governance, supra note 43, at 1412-26.

153 See Avi-Yonah, supra note 6, at 1212-31.

154 See Avi-Yonah, supra note 102, at 655-59.

155 See id.; $c f$. FRIED, supra note 6, at 203.

156 See FRIED, supra note 6, at 202-3.

${ }^{157}$ See id.

158 See id.

${ }^{159}$ See Atkinson \& Stiglitz, supra note 144, at 74. 
tolls. ${ }^{160}$ Hotelling pointed out that tolls - on the use of a bridge, for example - create artificial scarcity and hence distortion; they push up the effective price of access to the infrastructure and thereby price some users out of the market, reducing usage. ${ }^{161}$ The proceeds of what amounts to a use-based tax are in fact the monopoly rents created by this artificial scarcity. ${ }^{162}$ It would be better, argued Hotelling, for the government to pay for infrastructure by taxing incomes. ${ }^{163}$

Hotelling himself pointed out that the argument could be generalized to apply to the choice between income and commodity taxation, not just tolls on infrastructure. Any tax directed at a specific commodity-not just the "use" commodity associated with infrastructure-would drive marginal buyers or sellers from the market, creating artificial scarcity and hence inefficiency. ${ }^{164}$ But Hotelling's argument begged the question whether there are any efficiency costs to the income tax: does the income tax, too, create artificial scarcity - in this case, of labor? ${ }^{165}$ Over the next few decades, the attempt to answer this question gave rise to what has come to be known as the double-distortion argument, which reached its highest level of mathematical formalization in Atkinson and Stiglitz's 1976 paper. ${ }^{166}$ The argument was that the income tax would not create as much inefficiencydistortion-as the commodity tax, because the income tax would create artificial scarcity only in labor markets, whereas commodity taxation would create artificial scarcity both in commodity markets and, because the prices of goods affect consumer purchasing power and hence the effective value of wages, in the labor market, as well. ${ }^{167}$

In retrospect, it is rather difficult to see why scholars of the time took this argument to be a deathblow to commodity taxation, because,

160 See Hotelling, supra note 144, at 242.

161 See id. at 245-46.

162 See id.

163 See id. at 242.

${ }^{164}$ See id.

165 See W. J. Corlett \& D. C. Hague, Complementarity and the Excess Burden of Taxation, 21 Rev. Econ. Stud. 21, 21 (1953); I. M. D. Little, Direct Versus Indirect Taxes, 61 ECON. J. 577, 580 (1951) ("[I]t was arbitrarily assumed that the supply of labour was constant; or, to put it in another way, that the consumption of one good, leisure, was unaffected by changes in its own or other prices. This is clearly an indefensible assumption which must be removed.").

166 For early statements of the argument see Edgeworth, supra note 145, at 568 \& n.1; HICKS, supra note 145, at 41. The "double-distortion" label is due to Chris William Sanchirico, Taxes versus Legal Rules as Instruments for Equity: A More Equitable View Exchange: Should Legal Rules Be Used to Redistribute Wealth, 29 J. LEGAL STUD. 797, 799 (2000).

167 See, e.g., Little, supra note 165 , at 580. 
underneath the math, it worked only by assuming away the second distortion for income taxation. ${ }^{168}$ Atkinson and Stiglitz simply assumed that whereas increases in a specific product's prices caused by a commodity tax do both make the product artificially scarce in relation to others and reduce hours worked as well, increases in wages paid by employers caused by an income tax make labor artificially scarce but somehow do not reduce consumption of some products relative to others. ${ }^{169}$ In Atkinson and Stiglitz's 1976 paper, as in all earlier formulations of the double distortion argument, there is no double distortion created by income taxation only because the link between commodity and labor market behavior used to reason from the distortion created by commodity taxation to distortion in the labor market is assumed away when the time comes to reason from the distortion created by the taxation of income to distortion in commodities markets. ${ }^{170}$ And the assumption is obviously poor: the richer a person is, the more the person buys of some goods (e.g., jewelry) relative to others (e.g., public transportation), and vice versa. ${ }^{171}$

The great irony of Atkinson and Stiglitz's 1976 paper was, again, that it seemed to strike a winning blow for progressive income taxation at almost the moment when the tax revolt made redistribution through the income tax politically impossible, forcing progressives to turn to some of the same alternatives that as an intellectual matter their progressive comrades Atkinson and Stiglitz had just apparently succeeded at undermining. In an example of intellectual blowback, the 1976 paper was transformed from a weapon into an obstacle, one that grew in power over time. ${ }^{172}$

Indeed, as matters stood in the early 1980s, Atkinson and Stiglitz's paper appeared to have only quite narrow implications. It appeared to establish only that actual commodity taxation - a tax on yachts, say - and its cousin, direct price or rate regulation (cousin because a governmentmandated low price is like a tax paid to buyers) distort more than the income tax. This did not present much of a problem because then, as now, neither commodity taxation nor rate regulation held great appeal for progressives, who were not immune to the libertarianism that had inspired

\footnotetext{
${ }^{168} C f$. Atkinson, supra note 145, at 601 ("[O]ne can well imagine that even this limited separability requirement may not in practice be met: for example in the case of leisure goods.").

169 See Atkinson \& Stiglitz, supra note 144, at 68 ("If the utility function is weakly separable between labor and all consumption goods [taken together], then no commodity taxation need be employed[.]).

${ }^{170}$ See Atkinson, supra note 145, at 600-602.

${ }^{171}$ See Walker, supra note 145.

172 See Woodcock, Making the Rich Pay More and the Poor Pay Less, supra note 143.
} 
the tax revolt on the right. ${ }^{173}$ Indeed, progressives were, at just that moment, working with conservatives to implement deregulation, which put an end to the price regulations that had once covered a quarter of the American economy by GNP. ${ }^{174}$ Commodity taxation also appeared excessively bureaucratic, centralized, and potentially tyrannical to the progressive mind, which was only more likely than the conservative mind to recommended it when health and safety seemed to require intervention, as in the case of cigarette taxation. ${ }^{175}$

What progressives wanted instead was to use private law rules - the law of contracts, property, and tort-to redistribute wealth at the market level. ${ }^{176}$ This appealed to progressives' libertarian leanings because private law rules determine the ability of persons to engage in self-help redistribution either directly or through the filing of private lawsuits. ${ }^{177} \mathrm{~A}$ liability rule for pollution with generous punitive damages could potentially enable average people to redistribute large amounts of wealth from big firms to themselves by taking matters into their own hands and filing lawsuits. ${ }^{178}$ Similarly, a constructive license for those who trespass in search of food could potentially allow the hungry to feed themselves. ${ }^{179}$ No

\footnotetext{
${ }^{173}$ Barbara Fried argues that progressives were also skeptical that rate regulation could effectively be applied to scarcity, as opposed to monopoly, rents, because of the difficulty of determining the costs of individual firms. See FrIED, supra note 6, at 200-201. But this neglects that the use of price regulation to attack monopoly rents also requires identification of the costs of individual firms, because these are needed to determine the competitive market price that firms must charge in order not to earn monopoly rents. Moreover, rate regulation statutes, which require "reasonable" pricing, are generally interpreted to require pricing at economic cost, rather than competitive pricing, and so must be understood actually to attack scarcity rents in practice, even if rate regulation is generally imposed only in natural monopoly industries. See J. Stephen Henderson \& Robert E. Burns, An Economic and Legal Analysis of Undue Price Discrimination 43 (1989) ("Traditionally, the zone of reasonableness has been understood to require cost-based rates.").

174 See Thomas K McCraw, Prophets of Regulation: Charles Francis adams, LOUIS D. BRANDEIS, JAMES M. LANDIS, ALFRED E. KAHN 266-70, 293 (1984); RICHARD H. K VIETOR, CONTRIVED COMPETITION: REgulation AND DEREgUlation IN AMERICA 16 (1996); Joseph D. Kearney \& Thomas W. Merrill, The Great Transformation of Regulated Industries Law, 98 CoLUM. L. REV. 1323, 1330-40 (1998).

175 Cf. Daniel A. Crane, Harmful Output in the Antitrust Domain: Lessons from the Tobacco Industry, 39 GA. L. REV. 321, 365-67 (2005).

176 See Duncan Kennedy, Law-and-Economics from the Perspective of Critical Legal Studies, in The New PalgraVe Dictionary of EConomics AND the LaW 465, 472 (Peter Newman ed., 2002).

177 See Kennedy, supra note 13, at 30-33.

${ }^{178}$ See id.

${ }^{179}$ See id.
} 
administrative state — just the court system — would be required. ${ }^{180}$ Until the reappearance of antimonopolism over the past few years, antitrust played almost no role in progressive aspirations to redistribute around the tax system, perhaps because antitrust's combination of aspects that seemed to promote individual freedom - such as the protection of free market entrywith aspects that were deeply statist - such as the breakup of large private firms by government — offended progressives' latent libertarianism as well.

Redistribution through private law seemed to escape the net of Atkinson and Stiglitz's 1976 paper until a duo of lawyer-economists made the inconvenient point that changing private law legal rules is equivalent to imposing commodity taxes. ${ }^{181}$ The generous liability rule for pollution is equivalent to a tax on whatever product the polluter makes, creating artificial scarcity and turning the resulting rents over to pollution victims. ${ }^{182}$ Similarly, the constructive license creates artificial scarcity in food-not, to be sure, with respect to the hungry, but with respect to those who buy, for

180 See id.

181 See Louis Kaplow \& Steven Shavell, Why the Legal System Is Less Efficient than the Income Tax in Redistributing Income, 23 J. LEGAL STUD. 667, 667, 680 (1994) (" $[\mathrm{R}]$ edistribution through legal rules offers no advantage over redistribution through the income tax system and typically is less efficient. ... Our result is analogous to results on optimal taxation. In simple cases, specific commodity excises are inefficient in the presence of an optimal income tax."); Louis Kaplow \& Steven Shavell, Should Legal Rules Favor the Poor - Clarifying the Role of Legal Rules and the Income Tax in Redistributing Income Exchange: Should Legal Rules Be Used to Redistribute Wealth, 29 J. LEGAL STUD. 821, 821 (2000) ("[T]he income tax and transfer system is a superior instrument for redistributing income."). Kaplow and Shavell cite Joseph E. Stiglitz, Chapter 15 Pareto Efficient and Optimal Taxation and the New New Welfare Economics, 2 HANDBOOK OF PUBLIC ECONOMICS 991, 40 (1987) ("If the utility function is separable between consumption and leisure ..., then all Pareto efficient tax structures entail no taxation of commodities."). The extension of the double-distortion argument to "government programs" was earlier made by Aanund Hylland \& Richard Zeckhauser, Distributional Objectives Should Affect Taxes but Not Program Choice or Design, 81 SCANDINAVIAN J. ECON. 264, 265 (1979) ("We have diverged from optimal income tax discussions in making government programs a major element of our model. To do so, we have assumed that benefits from such programs can be converted into an increased income equivalent."). It seems to have inspired an early contribution of Shavell's in this vein. See Steven Shavell, A Note on Efficiency vs. Distributional Equity in Legal Rulemaking: Should Distributional Equity Matter Given Optimal Income Taxation?, 71 AM. ECON. REV. 414, 414 (1981) ("[D] espite imperfect ability to redistribute income through taxation, everyone would strictly prefer that legal rules be chosen only on the basis of their efficiency."). I note, in connection with the reference to "lawyer-economists" in the text, that Shavell is technically an economist only; he does not hold a law degree.

${ }^{182}$ See Kaplow \& Shavell, Why the Legal System Is Less Efficient than the Income Tax in Redistributing Income, supra note 181, at 680. 
they cannot now buy as much and must pay more for it. ${ }^{183}$ It followed, argued these scholars, that if income taxation is a better way to redistribute than is commodity taxation, then income taxation is also a better way to redistribute than is manipulation of the rules of private law. ${ }^{184}$

This bombshell exploded across the legal academy, spraying shrapnel not just at progressives seeking to make the long march through the common law but also at much of the non-economically inclined legal professoriate. For the implication of the work of Ronald Coase that the choice of legal rule has distributive consequences had by now sunk in to the legal academy generally, and, as Kaplow and Shavell themselves delighted in pointing out, it was a small step from that realization to the realization that what really motivates most of the apparently non-economic, "fairness"based arguments that law scholars make for particular choices of legal rules is in fact concern about the distribution of wealth. ${ }^{185}$ Thus the legal academy generally was implicated in inadvertent participation in the long march to redistribute through legal rules, and indeed in seeking to redistribute wealth in ways that did more harm to the economy than necessary. Kaplow and Shavell's intervention had the paradoxical result of making the double-distortion argument - itself a child of left scholarshipinto a target of the left, which now vilified the argument as liberal centrism. ${ }^{186}$ The intervention also made the double-distortion argument a target of the legal academy more generally, giving rise to a literature of great size and longevity aimed at demolishing the argument from every possible angle. ${ }^{187}$ The size of this literature is due in part to the fact that in

\footnotetext{
183 See id.

${ }^{184}$ See id.

185 See Louis Kaplow \& SteVen ShaVell, FaIRness Versus Welfare 17, 43 (2009)

("In particular, it is our impression that most analysts of legal policy who attach importance to notions of fairness hold mixed normative views. That is, not only do they give weight to notions of fairness, but they also place weight, and perhaps significant weight, on how legal policies affect individuals' well-being - either because they understand individuals' well-being to be encompassed by some notions of fairness, or because they consider both fairness and individuals' well-being in reaching a final judgment."); ROBERT COOTER \& THOMAS UlEN, LAW \& ECONOMICS 98 (6th ed. 2012) ("If transaction costs equal zero and successful bargaining can cure inefficient laws, what difference does the law make? One answer is that the law affects the distribution of the cooperative product, which affects bargaining."); R. H. Coase, The Problem of Social Cost, 3 J.L. \& Econ. 1,7 (1960) ("Whether the $\$ 3$ is a payment which the cattle-raiser has to make if he adds the third steer to his herd [which it would be if the cattle-raiser was liable to the farmer for damage caused to the crop] or whether it is a sum of money which he would have received if he did not keep a third steer [which it would be if the cattle-raiser was not liable to the farmer for damage caused to the crop] does not affect the final result.").

${ }^{186}$ See Kennedy, supra note 176, at 468.

187 See, e.g., Richard L. Revesz, Regulation and Distribution, 93 N.Y.U. L. REV. 1489,
} 
1489 (2018) ("[T]ax policy is ill suited to provide compensation for significant environmental, health, and safety harms."); Zachary Liscow, Is Efficiency Biased, 85 U. CHI. L. REV. 1649, 1666 (2018) ("[T] here is at minimum a plausible case that distributional consequences will not be fully offset."); David Blankfein-Tabachnick \& Kevin A. Kordana, Kaplow and Shavell and the Priority of Income Taxation and Transfer, 69 HASTINGS L.J. 1, 8 (2017) ("Kaplow and Shavell's purported efficiency advantage of tax and transfer is cast as a comparison of tax and transfer to individual rules of tort or contract, without attention to the selection of underlying property arrangements[.]"); Lee Anne Fennell \& Richard H. McAdams, The Distributive Deficit in Law and Economics, 100 MinN. L. REV. 1051, 1052-53 (2016) ("[L]aw and economics has neglected a feature of reality that is no less foundational than that of positive transaction costs: the large and variable costs associated with the political impediments that must be surmounted to achieve welfare-maximizing distributive results."); Matthew Dimick, Should the Law Do Anything about Economic Inequality, 26 CORNELL J.L. \& PUB. POL'Y 1, 39-40 (2016) (“[T]axation can increase social welfare by redistributing income and reducing inequality, according to the principle of diminishing marginal utility of money. . . . [H]igher inequality can [therefore] justify greater taxation-and hence a larger economic distortion."); David Gamage, How Should Governments Promote Distributive Justice: A Framework for Analyzing the Optimal Choice of Tax Instruments, 68 TAX L. REV. 1, 9 (2014) ("As compared to raising all revenues through a labor income tax, . . raising some revenues through excise taxes can reduce taxpayer incentives to engage in forms of tax gaming that operate like claiming artificial or inflated labor income tax deductions."); David Gamage, On Double-Distortion Arguments, Distribution Policy, and the Optimal Choice of Tax Instruments, No. ID 2489678, 7 (2014); Zachary Liscow, Reducing Inequality on the Cheap: When Legal Rule Design Should Incorporate Equity as Well as Efficiency Note, 123 YALE L.J. 2478, 2482 (2014) ("[F] eatures other than income are often desirable bases for redistributing income, and legal rules may be institutionally betterequipped than taxes or the only option - to redistribute based on such nonincome features."); Brian Galle, Is Local Consumer Protection Law a Better Retributive Mechanism than the Tax System Tort Law In the Shadow of Agency Preemption, 65 N.Y.U. ANN. SURV. AM. L. 525, 526 (2010) ("While redistributive tort laws have costs that taxes do not, government cannot effectively satisfy a heterogeneous society's preferences for redistribution with a single national set of tax rules. Local tort rules can better capture a wide variety of preferences."); Richard S. Markovits, Why Kaplow and Shavell's Double-Distortion Argument Articles Are Wrong, 13 GEO. MASON L. REV. 511, 519 (2005) ("[E]ven if the relevant tax policies could [contrary to fact] be shown to be Pareto superior to the relevant legal rule adjustments, that demonstration would not guarantee the tax policy's greater moral desirability from all legitimate value-perspectives[.]"); Ronen Avraham et al., Revisiting the Roles of Legal Rules and Tax Rules in Income Redistribution: A Response to Kaplow \& (and) Shavell, 89 IOWA L. REV. 1125, 1130 (2004) ("[I]n light of the heterogeneity of individuals and in light of their ex ante behavioral adjustments, Kaplow and Shavell's theoretical model of a taxand-transfer alternative to redistributive legal rules is no longer simple. To the contrary, it is virtually impossible to implement."); Kyle Logue \& Ronen Avraham, Redistribution Optimally: Of Tax Rules, Legal Rules, and Insurance, 56 TAX L. REV. 157, 165 (2003) ("[W]hereas one institution may have a comparative advantage at measuring the particular type of inequality at issue, another institution may have a comparative advantage at doing the actual redistributing."); Sanchirico, supra note 166, at 800 ("It is true that Kaplow and Shavell's formal modeling does indeed produce the result that damages should always be set efficiently. Yet a close inspection reveals that this result does not in fact follow from the 
implicating the mainstream professoriate, as well as the left, Kaplow and Shavell's intervention, combined with percolation of Coasian thinking, pushed the mainstream to the left. It showed mainstream professors that they were actually progressive fellow travelers and forced them to defend their projects in explicitly distributive terms. Everyone, now, became interested in redistribution, even if, according to Kaplow and Shavell, they were going about it the wrong way. ${ }^{188}$

Progressives - and the legal academy more generally-need not have fretted as much as they did, at least about double distortion, because of the weakness of the "separability" assumption described above: reductions in income do distort commodity purchase decisions. ${ }^{189}$ But Kaplow added to double distortion a distinct objection that remains difficult to overcome even today: the objection that it is almost impossible to redistribute wealth accurately through intervention in individual markets because it is hard to determine overall effects on individual income or wealth without considering the effects on all markets of interventions in individual markets. ${ }^{190}$ Taxing yachts might not necessarily redistribute from rich to poor if yacht makers happen to pay their workers well. ${ }^{191}$ By contrast, taxing individual income or wealth strikes directly at the variable of interest to redistributors: if you want to tax the rich, tax the rich directly, not particular products that may or may not serve as good proxies for wealth. ${ }^{192}$ It is likely that this administrability argument will be the principal legacy of

logic of distortion counting. Rather, it follows from an implicit assumption that all agents are identical with respect to the tort system."); Christine Jolls, Behavioral Economics Analysis of Redistributive Legal Rules Symposium: The Legal Implications of Psychology: Human Behavior, Behavioral Economics, and the Law, 51 VAND. L. REV. 1653, 1656 (1998) ("Would an individual typically experience the same disincentive to work as a result of a more generous [to victims] tort regime as would be experienced as a result of a higher level of taxation? Behavioral law and economics suggests that the answer may be no[.]"). The author has also contributed to this literature. Woodcock, Making the Rich Pay More and the Poor Pay Less, supra note 143.

188 Well, not quite everyone. See, e.g., Richard H. Fallon, Should We All Be Welfare Economists?, 101 MICH. L. REV. 979, 1007 (2003) (accepting that, as far as pie maximization and division are concerned, pie maximization should be the main focus of legal rule choice, with pie division left to the tax system, but rejecting the notion that the purpose of the legal system, including tax policy, should be pie maximization and division, as opposed to achieving fairness on other normative senses).

189 See Atkinson \& Stiglitz, supra note 144, at 69; Atkinson, supra note 145, at 601 ("[O]ne can well imagine that even this limited separability requirement may not in practice be met[.]").

190 See Louis KAPlow, The TheOry OF TAXATION AND PUBlic ECONOMICS 21 (2011) ("It is usually best to use instruments that are most directly reated to the matter in question.").

${ }^{191}$ Cf. Crane, supra note 20, at 1208.

192 See KAPLOW, supra note 190, at 21. 
Kaplow and Shavell.

But it has shown no sign of actually stopping progressive interest in market-level redistribution. The persistence of this interest - there have been as many papers devoted to defending redistribution through private law rules published in recent years as there were when the attacks began in the late 1990s and early 2000s - reflects a continued progressive desire to make an end run around the political roadblock to taxation to achieve redistribution by other means. ${ }^{193}$ Indeed, it seems more likely at this stage that the epochal realignments currently underway in American politics will remove the premise for the long march-the political impossibility of redistribution through income taxation - than that progressives will accept the realities of the administrability argument.

But on the eve of its possible demise, the impulse toward market-level redistribution has reached new heights in the form of the progressive antimonopolism of the past three years or so, which quite self-consciously wishes to use antitrust and competition policy as a kind of surrogate to direct price regulation, deploying antitrust breakup to push prices down at big companies and relaxation of antitrust enforcement to allow the prices charged by smaller, and presumptively poorer, businesses to rise. ${ }^{194}$ Whether breaking big firms up really will bring prices down given the increase in production costs that breakup creates, and whether the increase in prices charged by small businesses will offset the lost wages to big firm employees, who typically earn more than employees at small firms, seems to play no more role in the contemporary antimonopolist's thinking than does the administrability problem of actually keeping track of the effects of all these price changes on the distribution of wealth. ${ }^{195}$ Why progressives should have chosen antitrust-long ignored by progressives who push market-level redistribution - as the latest locus for the march, and why they chose it now, is not at all clear from the project of redistributing around the tax system itself.

The answer lies outside of the academy, in the predicament of a unique political actor: the press.

\section{B. The Press and Politicians}

It is generally a mark of lack of intellectual seriousness-indeed, of crackpot conspiracism - to treat the press as the cause of things. To do that is to blame the messenger, to fail to make a deeper inquiry, and indeed to

\footnotetext{
193 See supra note 187.

${ }^{194}$ See Longman, supra note 10.

195 See ATKINSON \& LIND, supra note 9, at 64-67; Demsetz, supra note 65, at 2.
} 
throw one's lot in with authoritarians, who rail endlessly about bias in the media. ${ }^{196}$ There is good reason to append to every razor, from Occam's to Napoleon's, this: never attribute to the press a result that can be explained by any other means.

The reason not to blame the press is that, in any country in which entry into the journalism market is free, the press tends to speak with one voice only when the facts support what the press says, in which case the facts, and not biased reporting, are the cause of whatever catastrophe one wishes to explain. ${ }^{197}$ Absent some incontrovertible factual anchor, the press tends to splinter, each paper contradicting the others, each interpreting events in a different way, in which case even if one might reasonably attribute a particular outcome to the biased reporting of a particular paper, one certainly cannot attribute any particular outcome to the control of the press as a whole over the minds of readers. ${ }^{198}$

The American press's promotion of contemporary antimonopolism is an exception, because, for possibly the first time ever in the United States, the existence of the entire news industry is threatened, and so the interests of every news organization are aligned to an unusual degree. ${ }^{199}$ And they

196 See Juliane A. Lischka, A Badge of Honor?, 20 JoURnALISM STUD. 287 (2019).

197 See Ramsi Woodcock, Ruinous Competition in News, the Postal Internet, and the Three Laws of Techno-Legal Change, SSRN SCHOLARLY PAPER (Mar. 11, 2021), https://papers.ssrn.com/abstract=3802884 (arguing that the only thing that unites an ideologically-diverse readership is interest in the facts).

198 See Wolfgang Donsbach, Exposure to Political Content in Newspapers: The Impact of Cognitive Dissonance on Readers' Selectivity, 6 EUR. J. COMMC'N 155, 173, 179 (1991).

199 The last time the business model of the entire news industry was called into question was during the advent of radio, when it was thought that broadcast news would wipe out newspaper readership. See PAUL StARR, THE CREATION OF THE MEDIA: POLITICAL ORIGINS OF MODERN COMMUNICATIONS 376-77 (2006). That time, the "American Newspaper Publishers Association and major wire services, including the Associated Press," banded together and threatened to withhold news from the radio networks unless they agreed to limit the amount of news they put out over the air waves. As Paul Starr recounts,

[t]he networks agreed to provide only two five-minute newscasts a day, one late enough in the morning and the other late enough in the evening so as not to undercut the sales of either morning or evening papers. All radio news would have to be at least twenty-four hours old, no single item could be longer than thirty words, a single combined wire service bureau would supply all items, and every broadcast would end with the words, "For further details, consult your local newspaper."

Id. at 377. Demand for broadcast news during World War Two put an end to those limits. See id. at 376-78. But it turned out that they were not necessary to protect the news industry anyway, and broadcast was not the threat that it had appeared to be. The news industry remained immensely profitable for another half century, until the Internet came 
are aligned in a way that makes the promotion of antimonopolism deeply desirable for every reporter and every news outlet. For the past twenty years have seen the primary business model of the press-to use great reporting to attract readers and to use readership to sell ads - all but wiped out by the Tech Giants-primarily Google, Facebook, and Amazon. ${ }^{200}$ These companies offer e-commerce, search, and social media services that command far more attention than can newspapers, and so have competed successfully for advertising dollars that once flowed to newspapers, sending many papers to bankruptcy and creating a national crisis in newspaper funding. ${ }^{201}$ Amazon has also put pressure on book publisher margins through its aggressive development of the e-book market, dealing a further blow to the writerly class. ${ }^{202}$ In response, the news industry-each paper equally aggrieved by the rerouting of its advertising dollars to the tech giants - has, for the past three years or so, engaged in a ferocious campaign to use its most powerful weapon - the bully pulpit that is the industry's reporting - to advance the cause of antimonopolism. ${ }^{203}$ The industry appears to hope that antimonopolism will lead to the breakup of the tech giants and thence to the delivery of the press from the clutches of the firms that have out-competed it for advertising dollars. ${ }^{204}$

There are no studies of press attitudes toward the tech giants - this is an area that badly needs further research-and there is no evidence of

into its own two decades ago. See Robert G. Picard, The Economics of the Daily Newspaper Industry, in MEDIA ECONOMICS: THEORY AND PRACTICE 109, 109 (Alison Alexander et al. eds., 2003) ("The newspaper industry is the most profitable of all media industries and one of the most profitable of all manufacturing industries in the country."); Derek Thompson, The Collapse of Print Advertising in 1 Graph, THE ATLANTIC, https://www.theatlantic.com/business/archive/2012/02/the-collapse-of-print-advertising-in1-graph/253736/ (last visited Jun. 9, 2021); Fred Dews and Eric Bull, The Decline of Newspapers, in Four Charts, BROOKINGS (Oct. 23, 2014), https://www.brookings.edu/blog/brookings-now/2014/10/23/the-decline-of-newspapers-infour-charts/.

${ }^{200}$ See Woodcock, Big Ink vs. Bigger Tech, supra note 8.

201 See Bull, supra note 199; Thompson, supra note 199; Michael Barthel, Circulation, Revenue Fall for US Newspapers Overall despite Gains for Some, PEW RESEARCH CENTER, https://www.pewresearch.org/fact-tank/2017/06/01/circulation-and-revenue-fall-for-

newspaper-industry/; Elizabeth Greico, Fast Facts about the Newspaper Industry's Financial Struggles as McClatchy Files for Bankruptcy, PEW RESEARCH CENTER, https://www.pewresearch.org/fact-tank/2020/02/14/fast-facts-about-the-newspaper-

industrys-financial-struggles/; Penelope Muse Abernathy, The Loss of Local News: What It Means for Communities, THE EXPANDING NEWS DESERT, https://www.usnewsdeserts.com/reports/expanding-news-desert/loss-of-local-news/.

${ }^{202}$ See Woodcock, Big Ink vs. Bigger Tech, supra note 8.

${ }^{203}$ See id.

${ }^{204}$ See id. 
conspiracy. Whether the press has coordinated its promotion of antimonopolism or not, the interests of all news organizations and all journalists are sufficiently aligned to make it quite plausible that news organizations or journalists have acted independently to promote antimonopolism, pursuant to a diffuse anti-tech mood rooted in the competitive effects of technology on the industry. ${ }^{205}$

There is a great deal of anecdotal evidence that the press has in fact acted to advance antimonopolism in recent years, so far with great success. ${ }^{206}$ To the antitrust scholar, the most striking manifestation of the press's antimonopolism was its embrace of the work of antitrust scholar

205 This is particularly plausible for newspaper and print journalists, as opposed to broadcast news outlets and reporters, because newspaper and print journalists rely primarily upon news-based revenues for their daily bread. By contrast, broadcast news is usually an adjunct to a separate business - the sale of entertainment on a subscription basis through cable networking and, increasingly, streaming - that is immune to the Tech Giants' appeal to advertisers. Bloomberg News, which is an adjunct to Bloomberg's sale of finance and trading information, is another example of a news operation less threatened by the Tech Giants' advertising appeal. The author's subjective impression is that much of the antimonopolism in contemporary American journalism originates neither with broadcast outlets nor with Bloomberg.

206 The press's campaign has not gone unnoticed by other commentators, although its probable source in the competitive threat posed by the Tech Giants to newspapers has gone unremarked. Noted antitrust economist Carl Shapiro's bewilderment at the campaign is quite poignant:

Until quite recently, few were claiming that there has been a substantial and widespread decline in competition in the United States since 1980 . . . Y Yet, somehow, over the past two years, the notion that there has been a substantial and widespread decline in competition throughout the American economy has taken root in the popular press. . . . Since 2015, there has been a regular drumbeat in the press reporting on a supposed decline of competition in the United States. In October 2015, the Wall Street Journal, hardly an anti-business publication, wrote: "A growing number of industries in the U.S. are dominated by a shrinking number of companies". Later that month, the New York Times stated: "Markets work best when there is healthy competition among businesses. In too many industries, that competition just doesn't exist anymore." Eduardo Porter of the New York Times later connected increasing inequality with a decline of competition, under the title: "With Competition in Tatters, the Rip of Inequality Widens". The Economist, a highly respected publication regarding economic policy, has been especially sharp and persistent in asserting that there has been a substantial decline in competition in recent years. . . . The drumbeat continues. Business Week recently reported: "Market concentration in the U.S. has reached a threedecade high, while the government has opened fewer antitrust cases."

Carl Shapiro, Antitrust in a Time of Populism, 61 InT'L J. Indus. ORG. 714, 717-18 (2018). 
Lina Khan before she had even graduated from law school. ${ }^{207}$ No piece of student scholarship in law may ever have received the attention from the press that Khan's student note received in 2017 and 2018. The New York Times, for example, published a glowing full-page profile of Khan, a separate column based on the note, as well as two of Khan's own op-eds. ${ }^{208}$ The note was hardly news in antitrust circles; it does not appear to have changed the thinking of any antitrust scholar. But the appeal to a press that felt keenly that Amazon was part of a broader big tech problem that was destroying the press's livelihood is obvious. ${ }^{209}$

Khan's was not, however, the only academic or academic-adjacent voice to receive an incongruous level of attention from the press. Just as no student note may ever have received the journalistic attention that Khan's piece received, perhaps no law review article published by a non-academic lawyer may ever have received the sort of approving profiles in both the New York Times and the Wall Street Journal that a paper by Dina Srinivasan received in 2018 and 2019. ${ }^{210}$ But the appeal of a paper titled The Antitrust Case Against Facebook to a press that had seen Facebook eat its advertising revenues is, again, obvious. ${ }^{211}$

Surprising as it may sound, the practice of using puff pieces to advance a news organization's pecuniary interests is a well-worn trick of the news

207 See Lina M. Khan, Amazon's Antitrust Paradox, 126 YALE L.J. 710 (2017).

208 See David Streitfeld, Amazon's Antitrust Antagonist Has a Breakthrough Idea, N.Y. TIMES (Sep. 7, 2018), https://www.nytimes.com/2018/09/07/technology/monopolyantitrust-lina-khan-amazon.html; David Leonhardt, Opinion | Amazon vs. Barnes \& Noble, N.Y. TIMES (May 7, 2018), https://www.nytimes.com/2018/05/07/opinion/amazon-barnesnoble.html; Lina M. Khan, The Supreme Court Case That Could Give Tech Giants More Power, N.Y. TIMES (Mar. 2, 2018), https://www.nytimes.com/2018/03/02/opinion/thesupreme-court-case-that-could-give-tech-giants-more-power.html; Lina M. Khan, Amazon Bites Off Even More Monopoly Power, N.Y. TIMES (Jun. 21, 2017), https://www.nytimes.com/2017/06/21/opinion/amazon-whole-foods-jeff-bezos.html.

${ }^{209}$ See Woodcock, Big Ink vs. Bigger Tech, supra note 8.

${ }^{210}$ See Dina Srinivasan, The Antitrust Case Against Facebook, SSRN SCHOLARLY PAPER (Sep. 10, 2018), https://papers.ssrn.com/abstract=3247362; Jeff Horwitz, She Argued Facebook Is a Monopoly. To Her Surprise, People Listened., WALL ST. J. (Dec. 10, 2019), https://www.wsj.com/articles/yale-law-grads-hipster-antitrust-argument-against-facebookfindsmainstream-support-11575987274; Daisuke Wakabayashi, The Antitrust Case Against Big Tech, Shaped by Tech Industry Exiles, N.Y. TIMES (Dec. 20, 2020), https://www.nytimes.com/2020/12/20/technology/antitrust-case-google-facebook.html; Dina Srinivasan, Why Privacy Is an Antitrust Issue, N.Y. TIMES (May 28, 2019), https://www.nytimes.com/2019/05/28/opinion/privacy-antitrust-facebook.html.

${ }^{211}$ See Srinivasan, The Antitrust Case Against Facebook, supra note 210. In an interesting twist, the Wall Street Journal profile discloses that Srinivasan consults on the digital advertising market for Wall Street Journal parent company News Corp. See Horwitz, supra note 210 . 
trade. Here is Los Angeles Times reporter Michael Hiltzik reminiscing about how his former employer, the Buffalo Courier-Express, tried to fend off competition from Warren Buffett:

The Conners family, which owned the Courier-Express, mounted an aggressive defense by hiring Frederick Furth, a renowned antitrust lawyer from San Francisco with a history of going after big corporate game. The newsroom did its part by running a series of puff pieces about local judges who might find the case on their dockets. One article, which described a jurist who was known as a martinet on the bench but a sweetheart in his family circle, was given an unfortunate but irresistible headline I remember vividly as: "Judge loses firmness when he doffs his robe." 212

Hiltzik's experience at the Courier-Express bears a striking similarity to the press's current campaign in that the current campaign, too, involves an attempt to leverage reporting in service of antitrust intervention designed to stop competition from a rival that offers consumers (here advertisers; in the case of the Courier-Express, newspaper readers) a better product. ${ }^{213}$ Buffett's paper was offering Sunday readers free Sunday delivery if they were to subscribe to the paper seven days a week, something that the Courier-Express, as a Sunday-only paper that was unable to recoup promotional costs by selling on the other six days of the week, could not match. ${ }^{214}$ Where the Hiltzik's experience differs from the press's current campaign against the Tech Giants is that the campaign against the Tech Giants involves the entire press. ${ }^{215}$

That has made the press's campaign particularly effective at influencing politicians, if not academics, because, for politicians, support from the entire press-left and right-is of the very highest value in elections. Indeed, although the puff pieces about academics have exerted a certain amount of influence over the minds of media-hungry scholars eager to share in the press's promotional largesse, there remains surprisingly little

\footnotetext{
${ }^{212}$ Michael Hiltzik, Column: How Warren Buffett, Who Says the News Business is 'Toast,' Tried to Kill My First Paper, LOS Angeles Times (Jun. 4, 2019), https://www.latimes.com/business/hiltzik/la-fi-hiltzik-buffett-omaha-newspapers20190604-story.html.

${ }^{213} I d$.

${ }^{214} I d$.

${ }^{215} I d$.
} 
antimonopolism within the academy itself. ${ }^{216}$ Not so among the surprising coalition of politicians on both the left and right who today are pushing for legislation on a par with the old no-fault monopolization legislation that was defeated in the 1970s. ${ }^{217}$ As The New York Times's own Ben Smith has written:

[T] he power of the press, even nowadays, makes it a formidable political force. Rupert Murdoch's bareknuckled News Corp.-born in Australia and broadly loathed by its more genteel and progressive global peers - has long led the fight to claw back revenue from the tech giants, and hostility to Google bleeds through the pages of The Times of London and Fox News's airwaves. . . . While much of the American media rejects the idea that it is crusading in its pages to support its publishers' business agenda, most news executives in this country share a viewpoint on the platforms, having seen them pull advertising dollars from the news business and spread misinformation at the expense of professional journalism. And even as the platforms employ armies of powerful lobbyists, politicians remain eager to please the press that covers them. ${ }^{218}$

\footnotetext{
${ }^{216}$ See Woodcock, Big Ink vs. Bigger Tech, supra note 8.

${ }^{217}$ See, e.g., Anti-Monopoly and Competition Restoration Act of __ $§ 6(\mathrm{~b})(4)(\mathrm{D})$ ("It shall be a presumptive abuse of market power under this section for a person with market power to engage or attempt to engage in the following conduct: . . Serving as both a platform and a merchant that competes with third-party merchants."), https://www.hausfeld.com/uploads/documents/2019_12_02_warren_draft_antitrust_bill.pdf ; Trust-Busting for the Twenty-First Century Act $\S 3(\mathrm{c})(2)$ (prohibiting acquisitions by any firm with a market capitalization in excess of $\$ 100$ billion), https://www.hawley.senate.gov/sites/default/files/2021-04/The\%20Trust-

Busting\%20for\%20the\%20Twenty-First\%20Century\%20Act.pdf; Subcommittee on Antitrust, Commercial, and Administrative Law of the Committee on the Judiciary of the United States House of Representatives, Investigation of Competition in Digital Markets: Majority Staff Report and Recommendations 20 (2020) (calling for "[s]tructural separations and prohibitions of certain dominant platforms from operating in adjacent lines of business"); Shira Ovide, How Klobuchar and Hawley See Things When It Comes to Technology, N.Y. TiMES (May 13, 2021), https:/www.nytimes.com/2021/05/13/books/amy-klobuchar-antitrust-josh-hawley-tyrannybig-tech.html.

${ }^{218}$ Ben Smith, Big Tech Has Crushed the News Business. That's About to Change., N.Y. TIMES (May 11, 2020), https://www.nytimes.com/2020/05/10/business/media/big-tech-hascrushed-the-news-business-thats-about-to-change.html.
} 
This is a startling admission from a paper that has played a central role in creating contemporary antimonopolism. ${ }^{219}$

The major cases filed against Google and Facebook — not coincidentally the two tech giants most closely implicated in the demise of newspapers' ad-based business model - are another dividend paid on the press's campaign. ${ }^{220}$ The haste of the Trump Administration to bring both of those cases before the 2020 presidential election-Attorney General Barr even had to face down a revolt of Justice Department Antitrust Division staff to do so-suggests that the press's drumbeat of articles casting Google and Facebook as monopolies had managed to convince the Trump campaign that antitrust would be a winning electoral issue, despite the fact that polls have repeatedly shown that, however much the press may hate the Tech Giants, the public continues to adore these companies, which have revolutionized the way Americans live their lives. ${ }^{221}$

Although some of the antimonopolists that the press has promoted fervently believe that antimonopolism is a viable solution to the problem of inequality, the press itself may not much care whether antimonopolism works as intended. ${ }^{222}$ Indeed, the broader appeal of antimonopolism as ideology or intellectual movement helps not the press except insofar as it serves to galvanize a coalition that will come to its aid by smashing the Tech Giants. It is the presence of this extraordinarily powerful institution promoting antimonopolism, not any new theoretical breakthrough regarding the usefulness of antitrust at fixing inequality, that created the immediate impetus for the rapid rise of antimonopolism over the past few years.

\section{Anti-Statism as Explanation}

Contemporary American antimonopolism is, in the final analysis, a peculiarly American phenomenon that reflects the powerful current of antistatism that runs through American political culture on the left as well as

${ }^{219}$ See Woodcock, Big Ink vs. Bigger Tech, supra note 8.

220 See Complaint, United States v. Google LLC, No. 1:20-cv-03010 (D.D.C. 2020); Complaint for Injunctive and other Relief, FTC v. Facebook, Inc., No. 1:20-cv-03590 (D.D.C. 2021).

${ }^{221}$ See Katie Benner \& Cecilia Kang, Justice Dept. Plans to File Antitrust Charges Against Google in Coming Weeks, N.Y. TIMES (Sep. 3, 2020), https:/www.nytimes.com/2020/09/03/us/politics/google-antitrust-justice-department.html; Casey Newton, This is How Much Americans Trust Facebook, Google, Apple, and Other Big Tech Companies, THE VERGE, https://www.theverge.com/2020/3/2/21144680/vergetech-survey-2020-trust-privacy-security-facebook-amazon-google-apple (last visited May 18, 2021).

${ }^{222}$ See Longman, supra note 10. 
the right. ${ }^{223}$ It is unlikely that antimonopolism would enjoy its current appeal on the left if the deeply anti-statist tax protest on the right had not taken place in the 1970s and persisted thereafter, causing progressives to give up-perhaps not altogether willingly, given their own anti-statist instincts - on redistribution through the income tax system and to open the door to embrace of market-based alternatives, including, eventually, antitrust. $^{224}$ Anti-statism also surely plays a role in the enthusiasm with which progressives have sought to undermine the case for tax and transfer in favor of redistribution through private law, and thereby to transform the poor into masters of their own redistributive fates. ${ }^{225}$ Anti-statism can be found in equal measure in the resort of the press to appeals to antitrust, as opposed to the direct state subsidization of media found in many other Western democracies, to solve the crisis in media funding occasioned by the tech giants. ${ }^{226}$ The press's appeal to antitrust is admittedly also a kind of appeal to the state, both because it calls upon the courts to reshape markets and because it is the government that is bringing antitrust cases against Google and Facebook, not the press itself. As a competitor that has lost out on technological grounds, the press could never win an antitrust case against these companies. ${ }^{22}$ But the press's appeal to antitrust is an appeal to smash firms and thus to bring greater anarchy to the market, which the press hopes it can exploit, rather than a truly statist attempt to have government stabilize the press directly. Indeed, antitrust is a sort of middle ground between the pure anti-statism pursued by progressives in their long march to redistribute through private law regimes like property, tort, and contract, and the pure statism of tax and transfer. ${ }^{228}$

The peculiarly American circumstances in which antimonopolism has arisen suggest that other jurisdictions considering following the antimonopolists' siren song should proceed with caution. Americans only became interested in market-based redistribution because American antistatism took tax and transfer, which both the original American

\footnotetext{
223 See David A Moss, When All Else Fails: Government as the Ultimate Risk MANAGER 317 (2004) ("There can be no doubt that Americans have traditionally harbored deep anti-statist sentiments.").

${ }^{224}$ See MARTIN, supra note 7, at 2-15; BROWNLEE, supra note 7, at 182-83.

${ }^{225}$ See Kennedy, supra note 13, at 30-33.

${ }^{226}$ See Woodcock, Big Ink vs. Bigger Tech, supra note 8; Rasmus Kleis Nielsen, 'Frozen' Media Subsidies during a Time of Media Change: A Comparative Analysis of Media Policy Drift in Six Western Democracies, 10 Global Media AND CommuniCation 121, 125-30 (2014).

227 See Herbert HovenKamp, Federal Antitrust Policy, the LaW of Competition AND ITS PRACTICE 406 (6th ed. 2020); Ramsi A. Woodcock, The Obsolescence of Advertising in the Information Age, 127 YALE L.J. 2270, 2309-14 (2018).

${ }^{228}$ See supra Section III.A.
} 
progressives and Piketty agree is the only way to solve the problem of inequality, off the table. In many other jurisdictions, however, tax and transfer is politically feasible, and, because it is also more effective at attacking inequality, ought to be pursued first. ${ }^{229}$ The prominence of antimonopoly rhetoric in the American press, the profusion of cases against Google and Facebook, and any new antitrust legislation that may follow, should not be seen as the expression of a new American intellectual consensus that antitrust is a useful tool in the fight against inequality, but rather as the expression of an attempt by a uniquely powerful industry to find a solution to a funding crisis in newsgathering that most other countries would solve using government.

\section{ANTIMONOPSONISM AND LABOR}

Contemporary antimonopolism is as much concerned with monopolymeaning seller power used to raise prices charged to consumers-as it is with its close cousin, monopsony, which is buyer power used to depress prices paid to input sellers. ${ }^{230}$ Indeed, the movement's focus on protecting vulnerable sellers, understood to mean workers (who sell their labor) and small suppliers, against monopsonistic buyers, has perhaps received more interest and support from academia than any other area of antimonopolism. Some have shown that employer power in labor markets depresses wages. ${ }^{231}$ Others have argued that although current antitrust rules limiting the acquisition and maintenance of seller power apply with equal force to buyer power, antitrust's nomenclature has been a barrier to enforcement of these rules against buyer power. ${ }^{232}$ They have advocated renaming antitrust's "consumer welfare" standard the "trading partner" welfare standard, or a variant thereof, to emphasize that antitrust considers harms inflicted on workers or small suppliers by monopsonistic buyers of equal importance to harms to consumers inflicted by monopolistic sellers. ${ }^{233}$ And some have called for treating harms inflicted by monopsonists, particularly those inflicted against workers, as more important than harms against consumers, so that in cases in which breakup of a monopsonist would harm

\footnotetext{
${ }^{229}$ See supra Part II.

230 See, e.g., Debbie Feinstein \& Albert Teng, Buyer Power: Is Monopsony the New Monopoly?, https://www.arnoldporter.com//media/files/perspectives/publications/2019/04/buyer-power-is-monopsony-the-newmonopoly.pdf.

${ }^{231}$ See Alan Manning, Monopsony in Labor Markets: A Review, 74 ILR REV. 3, 6 (2021).

${ }^{232}$ See C. Scott Hemphill \& Nancy L. Rose, Mergers that Harm Sellers, 127 YALE L.J. 2090-92 (2018).

${ }^{233}$ See id.
} 
the firm's customers but benefit workers, antitrust would be required to carry out the breakup. ${ }^{234}$

Although antimonopsonists are self-consciously interested in protecting all small sellers, including both workers and small suppliers, their primary focus has so far been the worker, understood broadly to include both those who count as employees as a legal matter and those who formally qualify as independent contractors and therefore as small suppliers, but who might in another age have been employees as a formal legal matter. ${ }^{235}$ Antimonopsonists are primarily interested in the employee in the Amazon sorting facility, the Uber driver, and the church organist, although they would not consciously exclude the local machine shop making tiny screws for an Apple assembly facility from the ambit of their interests. ${ }^{236}$ Such labor-focused antimonopsonism is even more clearly driven by concerns regarding wealth inequality than is antimonopolism generally because workers are more obviously poor than is the mass of consumers that antimonopolism seeks to defend. Antimonopsonism seeks directly to increase the income of the masses, whereas antimonopolism seeks only to make products cheaper for everyone, including the idle rich. But, like antimonopolism, antimonopsonism, at least as applied to labor, is ultimately a poor method of attacking wealth inequality because its end goalcompetition-again leaves scarcity rents more or less untouched.

The same scarcity rents that firms generate in competitive sell-side markets through their control over scarce resources appear in buy-side markets as firms' demand for labor and other production inputs. The firm that earns scarcity rents on the sale of some product in a competitive product market, because the firm happens to own a technology that no competitor can reproduce, naturally has more money available to spend on hiring workers and purchasing inputs from suppliers, and so that firm will have a greater willingness to pay, and hence a higher demand, for workers and supplies. Indeed, scarcity, and the differing fortunes it creates for firms in sell-side markets, is one of the reasons for which demand for labor and other inputs can be depicted as downward sloping, as in the labor market depicted in Figure 13.

\footnotetext{
${ }^{234}$ See Eugene K. Kim, Labor's Antitrust Problem: A Case for Worker Welfare Note, 130 YALE L.J. 428, 447 (2020) ("[A] firm cannot justify a merger simply because it reduces labor costs by creating monopsony power.”).

235 See Longman, supra note 10 (giving, as examples of "small businesses" that antitrust should protect, ice skating instructors, animal breeders, music teachers, public defenders, doctors, dentists, home health aides, truck drivers, and Uber drivers).

${ }^{236}$ See id.
} 


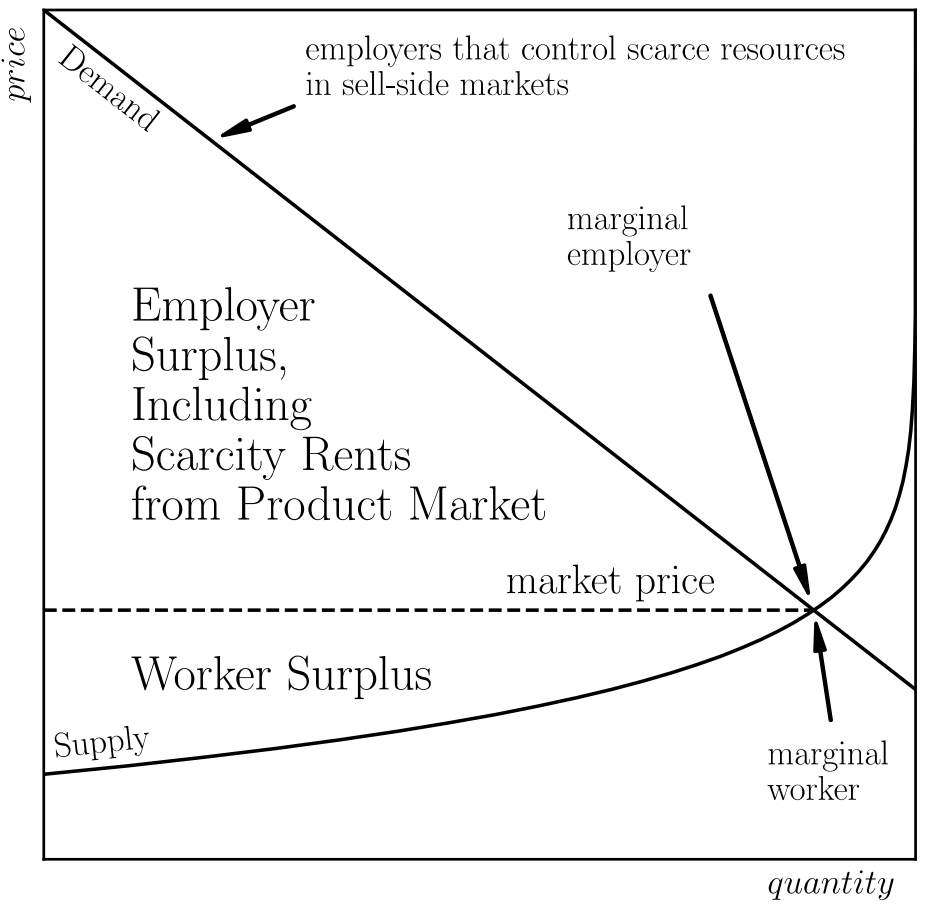

Figure 13

The firms that control scarce resources and earn scarcity rents in sell-side markets occupy the highest portions of the demand line in that figure. The surplus they generate in buy-side markets, equal to the area in the figure above the price line and below the demand line, is in part a measure of the rents that they generate in sell-side markets.

This suggests that policymakers should be able just as effectively to attack inequality by redistributing buyer surpluses in buy-side markets, including labor markets, as by redistributing seller rents in sell-side markets. The owner of scarce resources can be made to pay either by taxing him when he sells his product at a generous markup in competitive markets or when he buys his supplies and labor at prices far below the maximum that he is willing to pay given that markup. Moreover, antimonopsony can sometimes serve as the agent for redistribution of a firm's scarcity rents because an important characteristic of monopsony is that it increases the buyer's profits by enabling the buyer to dictate infracompetitive pricesprices that are below those that would prevail in a competitive market. Because a firm's rents in sell-side markets are net of its costs, and a firm's costs are reduced when the firm exercises monopsony power to reduce the prices it pays in supply markets, it follows that attacking monopsony power 
and driving those supply prices back up to competitive levels enables workers and other suppliers to capture some of a firm's scarcity rents for themselves and so amounts to redistribution of scarcity rents. This stands in stark contrast to antimonopoly, which, as we have seen, cannot attack scarcity rents in sell-side markets because, by definition, antimonopoly attacks only rents generated by supracompetitive pricing in those markets, not the scarcity rents that exist even under competitive pricing. ${ }^{237}$

But whether antimonopsony is able fully to redistribute scarcity rents depends on whether the limit to its redistributive reach - the competitive price - is likely to allocate to workers and suppliers the lion's share of those scarcity rents. Here antimonopsony comes up short. The most that antimonopsony can do is to drive prices up from the infracompetitive levels to which they have been pushed by monopsony power to the higher levels consistent with competitive markets. But, just as we saw in the case of sellside markets, whether competitive pricing is likely to redistribute a great deal of wealth or just a little depends on the relationship between inframarginal sellers and the marginal seller. ${ }^{238}$ If sellers-in this buy-side context they are workers or suppliers - are highly differentiated in the quality of the products and services that they provide, or if some are able to provide those products or services at far lower cost than others, then the competitive price set by the marginal seller will be substantially above the costs of the inframarginal sellers and will leave inframarginal sellers with a large share of surplus. ${ }^{239}$ Because that surplus in buy-side markets is ultimately traceable to scarcity rents in sell-side markets, the competitive price will therefore redistribute to sellers — workers and suppliers - a large share of scarcity rents. If, by contrast, sellers are not highly differentiatedworkers do not tend to have unique talents or skills and suppliers do not tend to sell differentiated products or to have radical cost advantages relative to each other - then there will be little difference between the cost of the marginal seller and those of the inframarginal sellers. The competitive price will, therefore, leave sellers with a small share of the surplus and hence redistribute to them a small share of the scarcity rents earned by firms in competitive markets.

The trouble with contemporary antimonopsonism as applied to labor is that workers are not highly differentiated. The curse of labor is that it is not scarce. Celebrities and the occupants of the relatively small number of highly-skilled jobs aside, most work can be done by most people, after a bit

\footnotetext{
${ }^{237}$ See supra Section II.B.1.b.

${ }^{238}$ See supra Section II.B.1.a.

${ }^{239}$ See supra Section II.B.1.a.
} 
of training. ${ }^{240}$ And most workers have about the same basic needs-the same production cost for their services-consisting of a bit of food and shelter. ${ }^{241}$ It follows that, celebrities and the highly-educated aside, no worker appropriates much in the way of surplus when wages are priced competitively. The marginal worker is only slightly less able to carry out his job, or needs only to be slightly better fed, than the inframarginal worker, and so the price necessary to get the marginal worker into the market is not substantially higher than the price needed to get any other worker into the market. As a result, workers, unlike their employers selling in product markets, can hardly turn a profit under competition, and so an antimonopsony policy that seeks to secure the competitive wage rate for workers will not go far toward ending inequality. ${ }^{242}$ In the context of our earlier discussion of sell-side markets, we are in Figure 4, which is reproduced in Figure 13 with the labels changed to reflect the buy-side, labor context. We are no longer in Figure 5, which depicts markets in which sellers earn hefty scarcity rents because they control scarce natural resources or technologies.

Given this reality, it is not surprising that the antimonopolism's most celebrated case to date has been brought by mixed martial arts sports stars against their promotion company. ${ }^{243}$ The profits denied average workers by

240 See Elka Torpey and Audrey Watson, Education Level and Jobs: Opportunities by State: Career Outlook: U.S. Bureau of Labor Statistics, https://www.bls.gov/careeroutlook/2014/article/education-level-and-jobs.htm (last visited Nov. 14, 2021) (reporting that only $5 \%$ of jobs require an advanced degree).

${ }^{241}$ We think that we have greater needs - such as the ability to purchase a computer or television-only because our profits, despite being small in relation to those earned by employers, are large enough to allow most of us to afford these things, and so we have come to expect them. But were the wage to fall and squeeze these things out of our lives, we would still work to eat, and so these things are not strictly necessary to make us ready, willing, and able to work-which is the definition of cost in the economic sense. See Woodcock, The Antitrust Case for Consumer Primacy in Corporate Governance, supra note 43 , at 1414 . By contrast, we would not take a job that did not pay us enough to eat, for we are better off starving at our leisure than starving on the job.

242 Antimonopsonists estimate, for example, that employer monopsony depresses wages by as much as $20 \%$. See José Azar et al., Labor Market Concentration, J. HuMAN RESOURCES 1218,1218 (2020). If one were generously to interpret a return to competitive wages as increasing, in the long run, the share of wealth controlled by the bottom $90 \%$ of Americans by $20 \%$, entirely at the expense of the richest $1 \%$, that bottom $90 \%$ would control a mere $30 \%$ of wealth and the richest $1 \%$ would continue to control $35 \%$ of the nation's wealth. See The Distribution of Wealth in the United States and Implications for a Net Worth Tax, EQUITABLE GROWTH (Mar. 21, 2019), http://www.equitablegrowth.org/the-distribution-ofwealth-in-the-united-states-and-implications-for-a-net-worth-tax/ (reporting that the bottom $90 \%$ control a quarter of national wealth and the top $1 \%$ control $40 \%$ of national wealth).

243 See Kevin Draper, Fighters Win Key Ruling in Case That Could Upend U.F.C.' Business, N.Y. TIMES (Dec. 10, 2020), https://www.nytimes.com/2020/12/10/sports/ufc- 
monopsony, although too small significantly to move the needle on inequality, as we have seen, are nevertheless substantial enough to fund major class action lawsuits. ${ }^{244}$ But it makes sense that the first labor antimonopsony lawsuits would be brought by distinctly non-average workers, for stars (and the well educated) are alone scarce enough to generate substantial scarcity rents in the labor market and so they stand to gain the most from antimonopsonism. Indeed, stars and the well-educated occupy a position closer to that of business owners than to that of the average worker, for their scarcity makes them more likely to take the lion's share of the surplus in the markets in which they compete, and so they are more like to be on the happy side of the wealth gap. ${ }^{245}$ It follows that monopsony does not deprive these special workers of equality so much as a spot in the one percent, and antimonopsony works to retore that spot to them. It is another irony of antimonopsonism as progressive cause that its major achievement thus far has been to get mixed martial arts stars a bit closer to being rich, rather than equal. ${ }^{246}$

lawsuit.html; Kajan Johnson, et al. v. Zuffa, LLC, et al., No. 2:21-cv-01189 (D. Nev.); Cung Le, et al. v. Zuffa, LLC d/b/a Ultimate Fighting Championship and UFC, No. 2:15cv-01045-RFB-BNW (D. Nev.).

${ }^{244}$ If, for example, a court were to conclude that Amazon had monopsonized labor markets and that hourly wages would be $20 \%$ higher were it not for Amazon's monopsony power, then, if all 950,000 Amazon employees were hourly workers, and given that Amazon pays a minimum wage of $\$ 15$ per hour, the loss suffered by workers for every hour worked would be at least $\$ 28.5$ million, and plaintiffs could recover three times that under antitrust's treble damages rule, for a total haul of $\$ 85.5$ million per hour worked. See Azar et al., supra note 242, at 1218 (arguing that labor monopsony depresses wages by 20\%); 1

in Every 169 U.S. Workers is Now Employed by Amazon, NBC NEWS, https://www.nbcnews.com/business/business-news/amazon-now-employs-almost-1million-people-u-s-or-n1275539; Why Amazon Is Flooding the Country With \$15 Minimum Wage Ads, VICE, https://www.vice.com/en/article/y3gj87/why-amazon-is-flooding-thecountry-with-dollar15-minimum-wage-ads. A lawsuit based on monopsonization over the course of a single 40-hour week of labor by the full company would, then, give rise to damages of $\$ 3.42$ billion, far more than enough to bankroll a vigorous class action lawsuit.

${ }^{245}$ See Jonathan Rothwell, Make Elites Compete: Why the 1\% Earn so Much and What to Do about It, BROOKINGS (Mar. 25, 2016), https://www.brookings.edu/research/make-elitescompete-why-the-1-earn-so-much-and-what-to-do-about-it/ (citing data showing that the groups with the largest representation in the top $1 \%$ of earners include the high-education professions of medicine, law, and accounting).

246 The twelve hundred plaintiffs in the case argue that between 2010 and 2017 the defendant's monopsonization of their labor market cost them $\$ 1.6$ billion in actual damages. See Draper, supra note 243. That averages out to $\$ 190,000$ per year each. Because they allege that this loss represents $40 \%$ of what they should have earned over the period, the elimination of the monopsony in this market would give the plaintiffs in the case average annual pay of $\$ 476,000$, which is well above the cutoff of $\$ 357,552$ for membership in the top one percent by income in 2021. See id.; Who Are the Top One 
An important consequence of the fact that average workers are not scarce is that, tax-and-transfer and price regulation aside, only monopoly power for average workers and the monopoly pricing of wages can meaningfully reduce inequality and indeed redistribute scarcity rents to average workers. This stands in rather stark contrast to the situation on the sell side that we considered earlier, in which the scarcity of sellers meant that monopoly power and monopoly pricing did not have important distributive effects. ${ }^{247}$ Because, on the buy side, the surpluses that drive inequality are taken by buyers (i.e., employers), rather than sellers (i.e., workers), monopoly pricing enables the have-nots, which here are the sellers, to claw back the value that competitive pricing would otherwise confer on buyers. On the buy-side, therefore, progressives ought to pine for the world depicted in Figure 14 in which workers are shown earning large monopoly rents by charging employers monopoly wages.

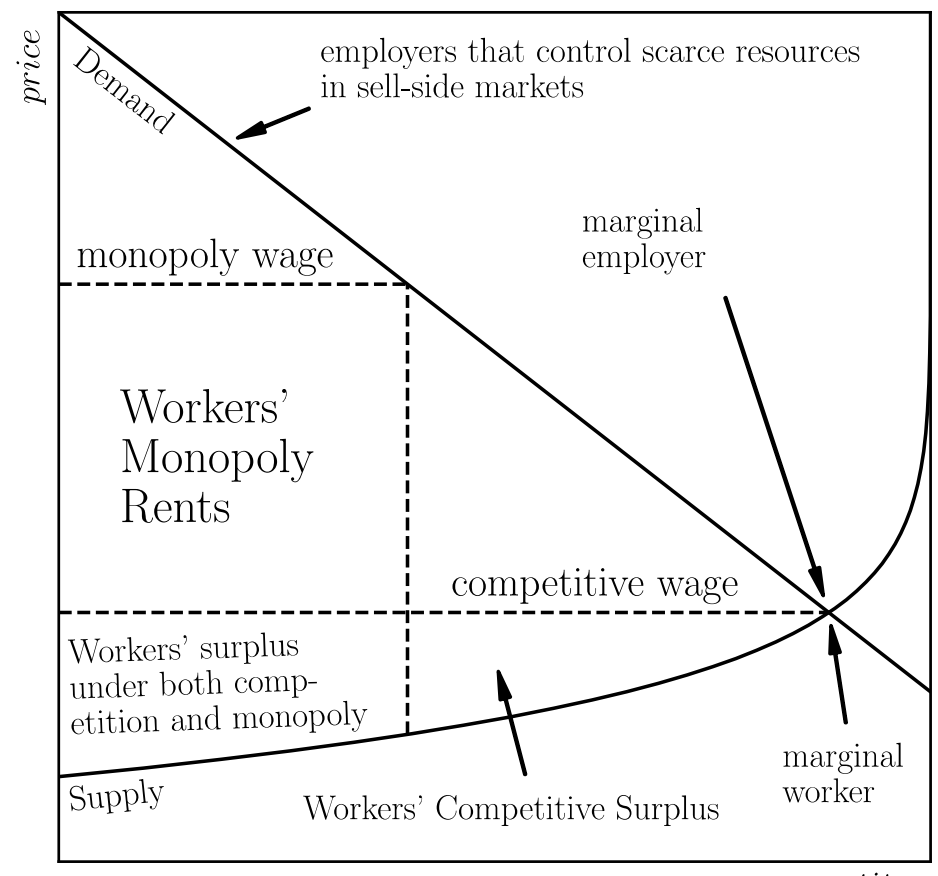

quantity

Figure 14

Percent by Income or Net Worth in 2021?, DQYDJ (Sep. 30, 2021), https://dqydj.com/topone-percent-united-states/.

${ }^{247}$ See supra Section II.B.1.b. 
Workers charge monopoly wages by unionizing, so the fact that only monopoly pricing can take a bite out of inequality in labor markets has the important implication that only unionization, and not antimonopsonism, can meaningfully attack wealth inequality. Labor-oriented antimonopsonismthe breaking up of big employers to the end of promoting competitive pricing of wages - is, by contrast, a profoundly moderate, deradicalizing approach to inequality, because it does nothing that unionization cannot itself do, but caps the gains that can be had by workers at those consistent with the competitive wage rate, something that unionization does not do. Unionization can achieve whatever gains for workers that antimonopsonism can achieve because a union engaged in bilateral negotiations with a monopsony employer necessarily negotiates wages up to competitive levels in negotiating them up to even higher, labor-monopoly, levels. Thus unionization is already a complete solution to monoposony pricing and embrace of antimonopsonism as an independent project serves only to restrict progressive horizons from monopoly profits to workers' meagre profits under competition. Progressives of a century ago understood that unionization, not antimonopsonism, held the greatest promise for workers, which is why, rather than fight to turn the antitrust laws against employers, progressives of that period fought instead to keep the antitrust laws off the backs of unions. 248

Given the deradicalizing implications of antimonopsony, why has it become perhaps progressives' favorite flavor of antimonopolism? Antimonopsonism is, of course, just another part of the long march around the tax system, for workers could, like everyone else, be made equal through an aggressive tax and transfer regime, even were their wages to remain at monopsony levels. ${ }^{249}$ So progressive interest in antimonopsonism is plausibly driven by progressives' broader frustration at not being able to redistribute through taxation. What seems to have made antimonopsonism of particular interest to progressives, however, is that it is also part of a second long march around a different political barrier: unionization, which went into serious decline at about the same time as the tax revolt made redistribution through the income tax system politically impossible. ${ }^{250}$ Progressives have been unable to reverse workers' fortunes through new

\footnotetext{
${ }^{248}$ See Daniel R. Ernst, The Labor Exemption, 1908-1914 Symposium: The Sherman Act's First Century: A Historical Perspective, 74 IowA L. REv. 1151, 1162-72 (1988-1989).

${ }^{249}$ See supra Section III.A.

250 See Danielle Kurtzleben, The Decline of American Unions, in 7 Charts, Vox, https://www.vox.com/2014/9/1/6078697/decline-of-unions-united-states-worldwide-oecd (last visited Nov. 14, 2021).
} 
legislation making it easier to unionize, and better price regulation-the minimum wage-has proven difficult to secure. ${ }^{251}$ Progressives have therefore sought to leverage the press's love affair with antimonopolism by reconceptualizing the labor problem as a problem of strong employers rather than weak workers, and in so doing have brought to the antimonopsonist branch of antimonopolism an additional and particularly vocal constituency. Political moderates, who perhaps appreciate the deradicalizing nature of antimonopsonism better than the long marchers, have been only too happy to oblige, which explains why academic uptake of antimonopsonism has been far more enthusiastic than academic uptake of antimonopolism as a whole. ${ }^{252}$

\section{CONCLUSION}

The foundation of renewed interest in antitrust and inequality in a uniquely American anti-statism suggests that other jurisdictions considering using antitrust to address inequality should proceed with caution. As both the original American progressives, mainstream law and economics, and Thomas Piketty seem to agree, the tax system remains the most effective and radical tool for redistributing wealth. Any jurisdiction in which tax reform remains politically feasible ought to pursue tax reform first. Moreover, antitrust is not even a second- (or, more aptly, given the inefficiencies associated with taxation, third-) best solution. For antitrust's focus on eliminating only monopoly rents (and this only through the limited means of promotion of competition ${ }^{253}$ ) precludes antitrust from ever attacking the scarcity rents that are a major source of inequality. ${ }^{254}$

251 See Kate Andrias, Text, Labor Law Reform Is Essential, BoSTON REVIEW, https://bostonreview.net/forum/why-labor-movement-has-failed\%E2\%80\%94and-how-fixit/kate-andrias-labor-law-reform-essential (last visited Nov. 14, 2021); Evan Soltas, Everything You Need to Know about the Minimum Wage, Vox, https://www.vox.com/2014/5/21/18079894/minimum-wage-explained (last visited Nov. 14, 2021).

252 Notable moderates who have made contributions to antimonopsony in recent years include Eric Posner, Herbert Hovenkamp, and Scott Hemphill. See Hemphill \& Rose, supra note 232; Ioana Marinescu \& Herbert Hovenkamp, Anticompetitive Mergers in Labor Markets, 94 IND. L.J. 1031 (2019); Naidu et al., supra note 27; Suresh Naidu \& Eric A. Posner, Labor Monopsony and the Limits of the Law, J. HUMAN RESOURCES (2021). For the academic reception of antimonopolism more broadly, see Woodcock, Big Ink vs. Bigger Tech, supra note 8.

${ }^{253}$ See Woodcock, The Antitrust Duty to Charge Low Prices, supra note 96, at 1755-60 (arguing limiting antitrust to the promotion of competiton prevents antitrust from carrying out its mission the maximize consumer welfare).

${ }^{254}$ See supra Part II. 
Other alternatives, such as the reform of private law rules of property, contract, and tort originally espoused by progressives making the long march to redistribute around the tax system, would in fact be more effective at targeting inequality. ${ }^{255}$ Unlike antitrust, private law rules can redistribute scarcity rents because these rules determine bargaining power at the most basic level; a seller who loses title to inventory loses all power to charge for it, for example, whereas a seller exposed to competition may not. And, also unlike antitrust, private law rules are not required to quit the field once a competitive price has been achieved. An exception to trespass for those earning less than median income could allow some consumers to appropriate inventories from sellers without paying for them, and that in turn could drive the effective per-unit price charged by the sellers, after accounting for the appropriated units, below the competitive price available in the market, thus redistributing some of those sellers' scarcity rents to consumers. Antitrust cannot achieve the same result because its remit ends with competitive pricing. Of course, redistribution through private law rules is highly imperfect relative to taxation. If trespassers take too much, they put the seller out of business, and attempts to regulate how much they take just converge to rate regulation and thence to taxation. But it says a lot about the peculiarity of contemporary American interest in antitrust as a redistributive vehicle that antitrust should present itself today as a solution to inequality even before reform of the private law.

\footnotetext{
${ }^{255}$ See Kennedy, supra note 13, at 30-33.
} 